(2) norden 



\section{Bioenergy in the Nordic- Baltic-NW Russian Region}

Status, barriers and future

Karin Hansen, Morten Ingerslev, Claus Felby, Jakob Hirsmark, Satu Helynen, Arunas Bruzgulis, Lars-Erik Larsson, Antti Asikainen, Aija Budreiko, Henn Pärn, Kent Nyström and Johan Vinterbäck.

TemaNord 2006:553 
Bioenergy in the Nordic-Baltic-NW Russian Region

Status, barriers and future

TemaNord 2006:553

(C) Nordic Council of Ministers, Copenhagen 2006

ISBN 92-893-1363-3

Print: Ekspressen Tryk \& Kopicenter

Cover:

Layout:

Cover photo:

Copies: 310

Printed on environmentally friendly paper

This publication can be ordered on www.norden.org/order. Other Nordic publications are available at www.norden.org/publications

Printed in Denmark

\section{Nordic Council of Ministers}

Store Strandstræde 18

DK-1255 Copenhagen K

Phone (+45) 33960200

Fax (+45) 33960202

\author{
Nordic Council \\ Store Strandstræde 18 \\ DK-1255 Copenhagen K \\ Phone (+45) 33960400 \\ Fax (+45) 33111870
}

www.norden.org

Authors:

Karin Hansen ${ }^{a}$, Morten Ingerslev ${ }^{a}$ and Claus Felby ${ }^{b}$ : Forest \& Landscape Denmark, Royal Veterinary and Agricultural University, ${ }^{\mathrm{a}}$ Hørsholm Kongevej 11, DK-2970 Hørsholm and ${ }^{\mathrm{b}}$ Rolighedsvej 23, DK-1958 Frederiksberg, Denmark

Jakob Hirsmark, Erik Larsson and Kent Nyström: SVEBIO - Swedish Bioenergy Association, Torsgatan 12, S-111 23 Stockholm, Sweden

Satu Helynen: VTT, P.O.Box 1603, Koivurannantie 1, FIN-40101 Jyväskylä, Finland

Arunas Bruzguli: Forest Owners Association of Lithuania (FOAL), Kalvariju 131-312, LT-08221 Vilnius, Lithuania

Antti Asikainen: Finnish Forest Research Institute, P.O.Box 68, FIN-80101 Joensuu, Finland

Aija Budreiko: Ministry of Agriculture Republic of Latvia, Forest Resources Department, Republikas laukums 2, LV-1981 Riga, Latvia

Henn Pärn: Estonian Agricultural University, Institute of Forestry and Rural Engineering, Department of ecophysiology, Viljandi Str. 18B, E-11216 Tallinn, Estonia

Johan Vinterbäck: Swedish Association of Pellet Producers (PiR), Torsgatan 12, S-111 23 Stockholm, Sweden

\section{Nordic co-operation}

Nordic co-operation, one of the oldest and most wide-ranging regional partnerships in the world, involves Denmark, Finland, Iceland, Norway, Sweden, the Faroe Islands, Greenland and Åland. Cooperation reinforces the sense of Nordic community while respecting national differences and similarities, makes it possible to uphold Nordic interests in the world at large and promotes positive relations between neighbouring peoples.

Co-operation was formalised in 1952 when the Nordic Council was set up as a forum for parliamentarians and governments. The Helsinki Treaty of 1962 has formed the framework for Nordic partnership ever since. The Nordic Council of Ministers was set up in 1971 as the formal forum for co-operation between the governments of the Nordic countries and the political leadership of the autonomous areas, i.e. the Faroe Islands, Greenland and Åland. 


\section{Table of contents}

Preface

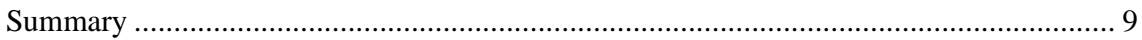

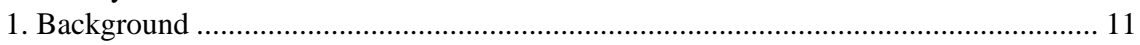

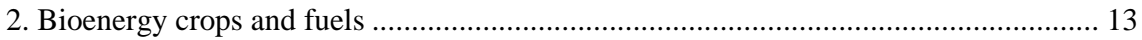

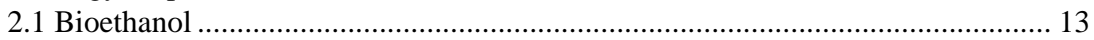

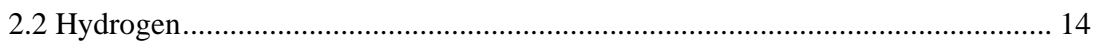

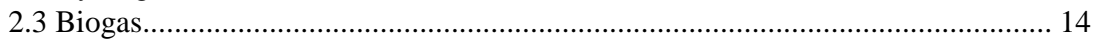

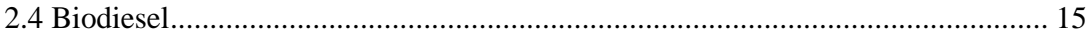

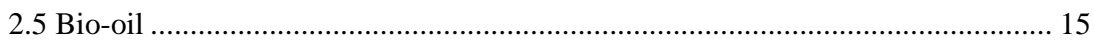

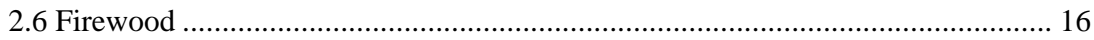

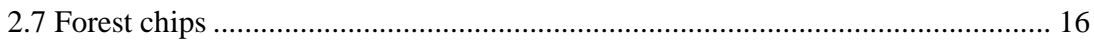

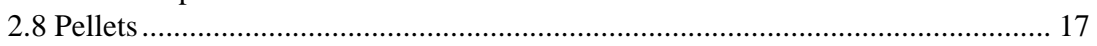

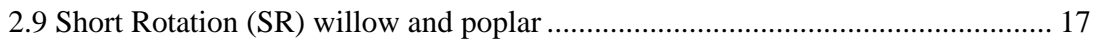

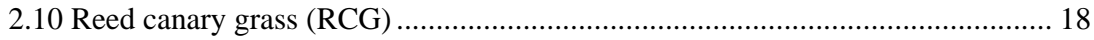

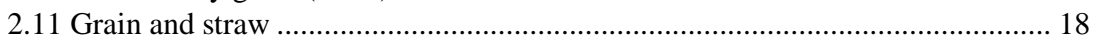

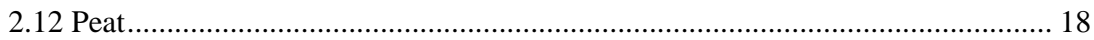

3. Current status on bioenergy in the Nordic-Baltic-NW Russian region .......................... 21

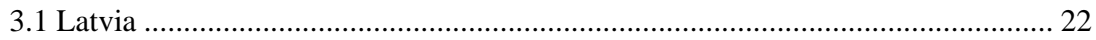

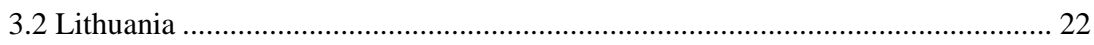

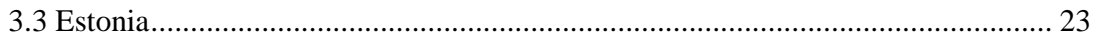

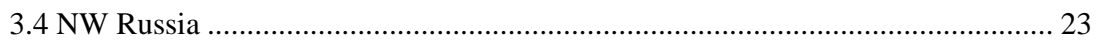

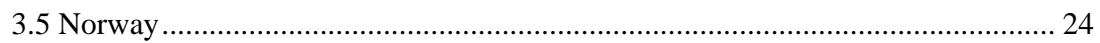

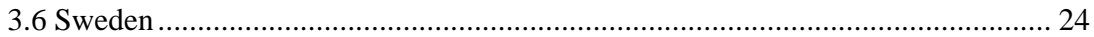

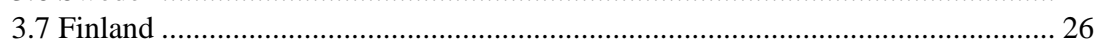

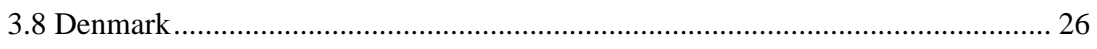

4. Plans for future increased use of bioenergy in the Nordic-Baltic-

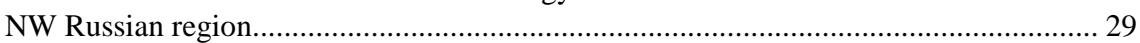

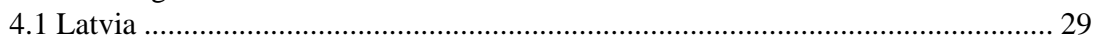

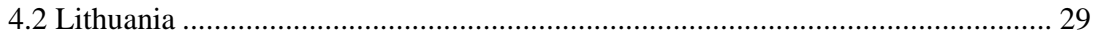

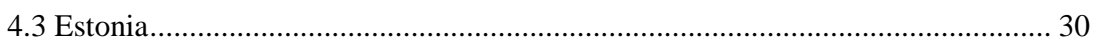

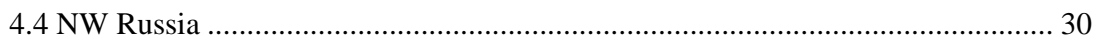

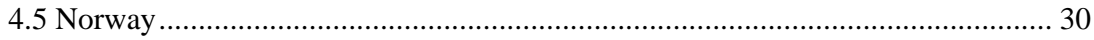

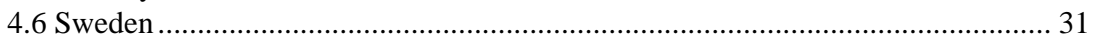

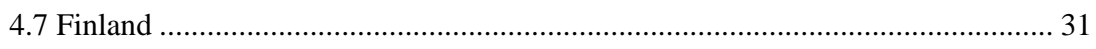

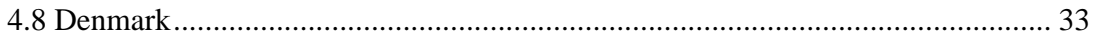

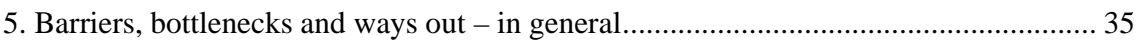

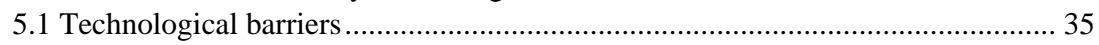

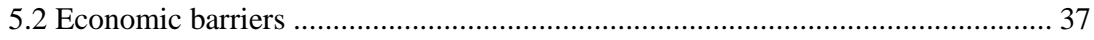

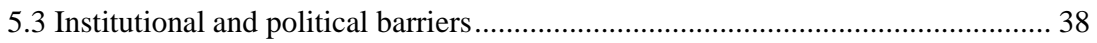

6. Barriers, bottlenecks and ways out - specifically ….............................................. 41

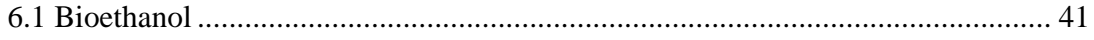

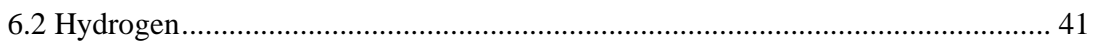

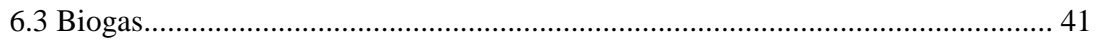

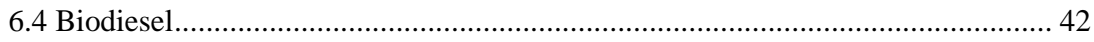

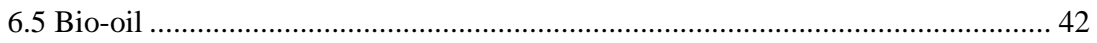

6.6 Thermal conversion of biomass to biofuels for transportation ............................ 42

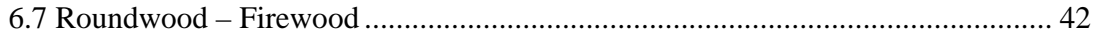

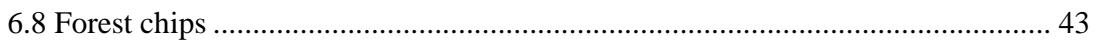


6.9 Pellets

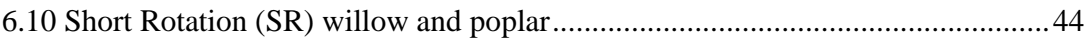

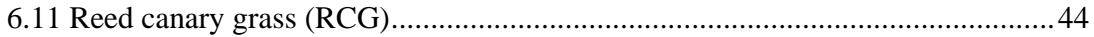

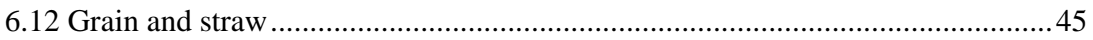

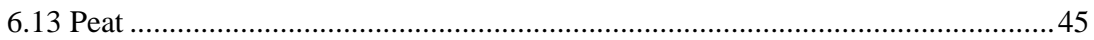

7. Breaking the barriers - political decisions and strategies.............................................4 47

8. Inventions and developments, which created a strong regional position.......................49

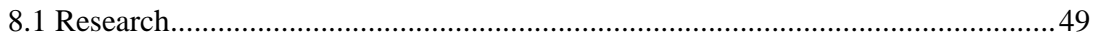

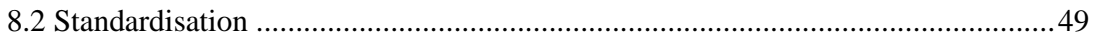

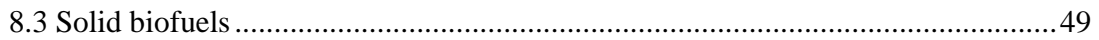

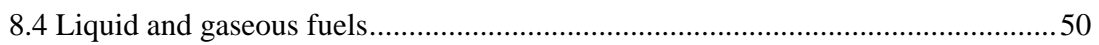

9. Good cases and successful examples in the Nordic-Baltic-NW Russian Region ...........51

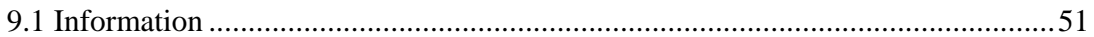

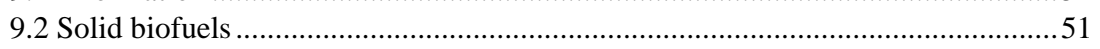

9.3 Liquid and gaseous fuels................................................................................ 52

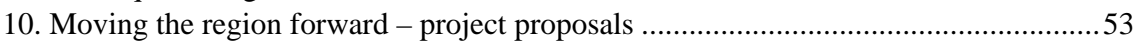

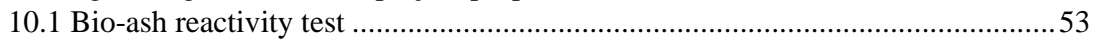

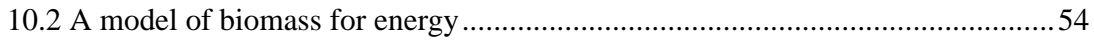

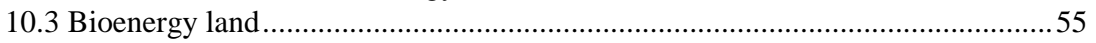

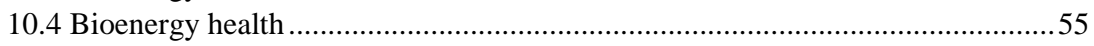

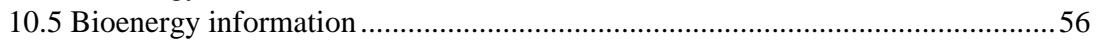

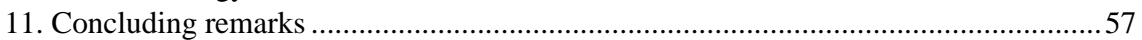

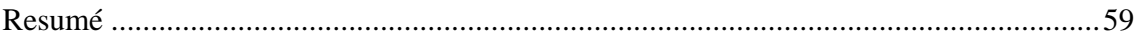

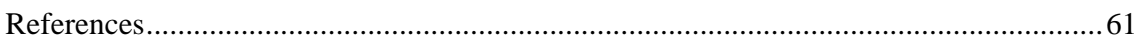

Appendix 1. List of interesting web sites on bioenergy in the region ..............................6 63

Appendix 2: List of projects on bioenergy issues fully or partly financed by the Nordic

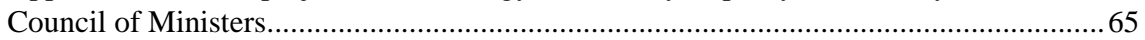




\section{Preface}

Bioenergy is a hot topic in the European Commission as well as in many European countries. Bioenergy has the potential to grow and become an important main source in a sustainable energy supply. Especially, in the Nordic and Baltic countries, forests are abundant and a long tradition of growing agricultural crops is evident. Therefore, this region has the possibilities for an increased use of bioenergy in the future.

In 2004, Forest \& Landscape Denmark were given the opportunity to run the project "Bioenergy as an environmental factor in the NordicBaltic-North-West-Russian Region” (project number 04-3) granted by Environmental Strategies in Agriculture and Forestry (MJS) in the Nordic Council of Ministers. This report is the outcome of the project. The report supplies a broad overview of the current and potential future use of bioenergy within the Nordic-Baltic-NW Russian region (Norway, Sweden, Finland, Denmark, Estonia, Latvia, Lithuania and NW Russia). Suitable actions and solutions for the overcoming of present barriers for increased sustainable use of bioenergy are discussed and specific proposals for the future development of bioenergy are given. The importance and need for holistic strategies and interdisciplinary efforts taking all part of the bioenergy chain into account is emphasized. Another deliverable from the project was a Nordic-Baltic-NW Russian seminar on bioenergy, which was held in Copenhagen on September $27^{\text {th }} 2005$.

The project has been largely interdisciplinary including players from different fields within bioenergy and giving room for cooperation between professionals from forestry and environmental sectors, national, regional and local government officials, bioenergy associations and entrepreneurs, policy makers, legislators and scientists. On beforehand, there was already good cooperation between the Nordic and the Baltic countries on bioenergy issues, however, the project has provided possibilities for further collaboration and mutual aid, which is needed in order to solve existing bottlenecks, carry the region forward and bring about increased use of bioenergy in the future.

The report was first written as a background paper for discussions at the Nordic-Baltic-NW Russian seminar on bioenergy. Presentations and discussions at the seminar gave input to updates of this report. Therefore, we thank all speakers and participants at the seminar for having taken active part in the discussions. Also, our deepest thanks go to people who professionally helped establishing the Nordic/Baltic seminar network and suggesting speakers.

Karin Hansen

Hørsholm 30 June, 2006 



\section{Summary}

Consumption of energy has increased more than 20\% in the European Union since 1985. Renewable energy sources, which are $\mathrm{CO}_{2}$-neutral, will be important in the future and bioenergy is one of the main sources presently considered in a sustainable energy supply. Today, worldwide bioenergy only makes a modest contribution to energy balances and receive a small proportion of research and development budgets. Bioenergy production thus is a juvenile industry, but a number of the main technical bottlenecks have already been solved.

In the Nordic and Baltic countries, the forest area covers a large percentage (approximately 50\%) of the total area. Still, the Nordic and Baltic countries have large unutilised forest fuel resources. The Nordic countries likewise have a long and strong tradition of growing food crops. The EU's set-aside policy, which encourages farmers to keep part of their land fallow, is making significant areas of land available. Growing biomass energy crops or increasing afforestation on this land can be considered in order to produce more renewable bioenergy. The Nordic and Baltic countries thus have a naturally large selection of biomass types to produce bioenergy from and, positively, plenty of biomass resources are still available. Also, technology development is progressing in this region.

On the other hand, many barriers to an increased and sustainable production and use of bioenergy are apparent in the Nordic-Baltic-NW Russian Region. To overcome these barriers, develop processes and progress, and obtain a valuable bioenergy-market a co-ordinated effort is necessary. The weight that politicians choose to put on issues like climate change, land use, independency of the fossil fuel supply, and environmental quality is of prime importance for the future use of bioenergy. An increased investment in long-term sustainable energy caused by wellthought-through political means of navigation will create possibilities for further expansion in the bioenergy sector. Political support, as e.g. introductory supportive subsidies, removal of legislative barriers, or securing of mandatory use of bioenergy, will therefore have a positive impact on the creation of a commercial market.

This report describes possible bioenergy crops and fuels in the NordicBaltic-NW Russian Region (Latvia, Lithuania, Estonia, NW Russia, Norway, Sweden, Finland, and Denmark) and analyzes the current status of production and use of bioenergy as well as the future plans for use in the region. The report also identifies barriers behind the bioenergy market growth as well as suitable actions and solutions for the overcoming of present barriers for increased sustainable use of bioenergy in the entire region. Especially, focus is placed on political decisions and strategies 
needed in order to break the barriers and move the region forward. Lastly, the report emphasizes the positive role of good cases and successful examples, identifies earlier regional inventions and developments, which so far created a strong position worldwide, and supplies specific proposals for the future development of bioenergy in the region. 


\section{Background}

Consumption of energy has increased more than 20\% in the European Union since 1985. Also, increased use of electrical energy is apparent specifically in developing countries. If the fossil fuel combustion continues to grow, a doubling of pre-industrial $\mathrm{CO}_{2}$ concentrations in the atmosphere could occur as early as 2030. Decreasing resources of fossil oil and gas and increasing emissions of carbon dioxide concentrations to the atmosphere points to the urgency of finding alternative solutions for the energy production. Renewable energy sources, which are $\mathrm{CO}_{2}$-neutral, will be important in the future and bioenergy is one of the main sources presently considered in a sustainable energy supply.

Worldwide bioenergy only makes a modest contribution to energy balances and receive a small proportion of research and development budgets. At present, bioenergy provides approximately $11-14 \%$ of the global energy supplies. Finland and Sweden have a leading role in Europe with high contributions of renewable energy sources to the total energy supply. However, the European Union and many of its member countries have set the target to increase the use of renewable energy sources considerably and a supply of $30-45 \%$ of the energy from renewables is planned by 2025-2050. Nevertheless, the goal to achieve the 2010 target of $22 \%$ of electricity consumption from renewable energy sources and the overall target of a $12 \%$ share of renewable energy use for all purposes is far from obtained. After evaluations in 2001 of the current progress in the EU15 the share of renewable energy had reached 6\%, which is not sufficient to reach the target value. The contribution of renewable energy resources to the energy economy can still be greatly increased. Therefore, EU calls for stronger commitment of Member States to achieve the 2010 targets on renewable energy use. On this background, the recent Green paper "Towards a European strategy for the security of energy supply" (European Commission, 2002) recommends high priority of research into new bioenergy technologies.

Forest is an essential element of the European cultural landscape. In the Nordic and Baltic region, the forest area covers a large percentage (approximately 50\%) of the total area. Sweden and Finland are on the forest fuel top ten in Europe. Still, the Nordic and Baltic countries have large unutilised forest fuel resources. In total, about 45 mill. $\mathrm{m}^{3}$ (90TWh) in the Nordic countries and about the same in the Baltic countries and NW Russia could be harvested for energy from the forests on a sustainable basis. The resources exceed 10 fold the current use. This biomass could serve as a source for liquid fuels for transportation as well as for heat and power generation. 
The Nordic countries likewise have a long and strong tradition of growing food crops. The EU's set-aside policy, which encourages farmers to keep part of their land fallow, is making significant areas of land available. Growing biomass energy crops like e.g. willow, rape, and reed canary grass or increasing afforestation on this land can be considered in order to produce more renewable bioenergy and to cope with mitigation of climate change. The Nordic and Baltic countries hereby have a naturally large selection of biomass types to produce bioenergy from.

There are, however, many barriers to an increased and sustainable production and use of bioenergy in both Europe and the Nordic-Baltic-NW Russian Region. This report looks at the current status of production and use of bioenergy in the Nordic-Baltic-NW Russian Region (Latvia, Lithuania, Estonia, NW Russia, Norway, Sweden, Finland, and Denmark). The report also contributes to the identification and analysis of barriers behind the bioenergy market growth and considers how these might be overcome in order to increase the use of bioenergy in the future in the entire region.

The report was produced as a product of the project "Bioenergy as an environmental factor in the Nordic-Baltic-NW Russian Region”. The project included an arrangement of a seminar on the subject, which took place in Copenhagen, September $27^{\text {th }} 2005$. The goal of the seminar was to identify suitable actions and solutions for the overcoming of present barriers for increased sustainable use of bioenergy. It was furthermore to point out the possibilities in the region. The challenge of the seminar was to formulate recommendations on how to overcome these barriers and supply specific proposals for the future development of bioenergy in the region. Furthermore, the meeting was an attempt for politicians and scientists to meet and start a dialogue on bioenergy issues.

This report was produced based on common knowledge and a number of references shown in the reference list at the end of the paper. The individual references have not been mentioned specifically in the text but rather used to produce an overview of the bioenergy status in the Nordic and Baltic countries. 


\section{Bioenergy crops and fuels}

Bioenergy is energy produced from sources of biological and renewable origin, normally derived from by-products of agriculture, forestry or fishery or in some cases purpose grown energy crops. The main biomass resources can be divided into conventional forestry, by-products from forest industries, short rotation forestry, agriculture crops and residues, oil-bearing plants, peat, and municipal solid waste. The technologies that are interesting for energy production from biomass are different kinds of fluidised bed, rotating grate and other types of furnaces for combustion and gasification and production of liquid biofuels. The end products of bioenergy systems can be used for heating, electricity supply and transport.

Solid biofuels include firewood, forest chips, pellets, briquettes, wood powder, peat, short rotation willow (Salix ssp.) and poplar (Populus spp.), grain and straw (triticale, oats, wheat, rye, barley or corn), reed canary grass (Phalaris arundinacea L.), Miscanthus (Miscanthus spp.), hemp (Cannabis sativa), oilseed rape (Brassica napus), sugar beet (Beta vulgaris) as well as wood residues from forest industry. Different forms of biofuels are produced from different biomass using different conversion methods. Liquid biofuels considered in the Baltic and Nordic countries could be rapeseed oil, ethanol, methanol and biodiesel. Gaseous biofuels could be biogas and hydrogen. Some of the most important forms in the region are described beneath.

\subsection{Bioethanol}

In Brazil and the United States, large ethanol programmes are existing and these countries account for more than $65 \%$ the global ethanol production. Here, ethanol $\left(\mathrm{C}_{2} \mathrm{H}_{5} \mathrm{OH}\right)$ is mainly produced from sugar cane and from corn and other starch-rich grains. Bioethanol is produced by hydrolysis by enzymes or acid treatment (break down of starch into sugar) followed by fermentation of the sugars into ethanol with the aid of yeast or other micro-organisms. These processes are very well developed and the production is competitive. In practice, the choice of raw material depends on what grows best under the prevailing climatic conditions and on the given soils. The result is a wide variety of ethanol feedstock, and hence many different production processes. Bioethanol can be used as a large-scale transportation fuel. It can be used in existing engines with little modification. It might be used as a primary fuel either in unblended form or with small amounts of gasoline (E85 = 85\% ethanol and 15\% 
gasoline blend). The technology for production of ethanol from cellulosic material is fundamentally different from that for production from food crops since it is more difficult to release sugars, which can be fermented. The processes are not so well developed yet. In Sweden, the use of bioethanol as a transport fuel has developed fast in these years and research into the processes of producing ethanol from cellulosic material have advanced (Borregaard in Sarpsborg delivers bioethanol to Sweden). Also, in Odense in Denmark the scaling up of processes in the production of ethanol from cellulosic material are advancing in these years.

\subsection{Hydrogen}

The dominant method of production of hydrogen is steam reforming of non-renewable natural gas, which is currently used to make more than $90 \%$ of all hydrogen. Alternative production methods include gasification (conversion of solids and liquids into hydrogen and carbon monoxide) and reforming of other fuels. Liquid biofuels are good alternatives. Biofuels being composed of hydrogen, carbon and oxygen such as ethanol has a high potential as hydrogen carriers. Hydrogen can be found on solid, liquid and gaseous form. When burning hydrogen you get water and energy and it is therefore altogether free from environmental pollution. Hydrogen can be used in fuel cells for production of electricity and heath. Safety when using hydrogen has to be really good and demands special solutions. A major problem for the use of hydrogen is the storage issue. The most common storage solution is to keep it under pressure (100-1000 bar) in tanks or in liquid form at minus 250 degrees ${ }^{\circ} \mathrm{C}$. Not only is high pressure required in order to store enough hydrogen, but also the small hydrogen molecule will leak from almost any container when in a gaseous or liquid form. However, the transformation into high pressure or liquid form demands up to $50 \%$ of the energy produced by the process. Another challenge is the cost, which still is way too high.

\subsection{Biogas}

Anaerobic digestion of farmyard manure as well as industrial and municipal effluent produces methane (biogas). Anaerobic digesters are widely distributed throughout China and India. They are ideal for rural areas since they improve sanitation as well as produce fuel and fertiliser. Countries such as Denmark, Germany and the Netherlands with large animal production, face problems with manure. The ability to convert manure into biofuel is a positive way of solving this waste problem. In this way, an environmental problem is solved and the energy produced can be looked upon and rated as a by-product. 
Biogas can be used as fuel for some types of fuel cells, like for example solid oxide fuel cells. The high operating temperatures of these cells combined with the materials used allow direct feeding of methane as well as carbon oxide or ammonia (and hydrogen). Among the challenges to be solved for such an application are improving life-time and resistance towards impurities in the fuel.

\subsection{Biodiesel}

Biodiesel is either made chemically by treating rapeseeds, sunflower seeds, soy beans or other sorts of vegetable oils with methanol to produce methyl esters (esterification), e.g. rapeseed oil methyl ester (RME) or mechanically by pressing the seeds. Rape is undoubtedly the most widely grown energy crop in Europe. The agricultural production of rape for food and fodder is already ongoing in the region. Rapeseed oil is made by cold- or warm pressing the rapeseeds. Rapeseed oil is heavy oil with a high viscosity and it is not flammable and unhealthy. Rapeseed oil can be used for both heating and transport, after a smaller modification of the engine. Biodiesel can be burned directly in diesel engines, however, in contrast to rapeseed oil it is flammable. Rapeseed oil and biodiesel can both be transported and stored as existing fossil fuel oils, which means that no new technology is needed in this area. An advantage of the use of biodiesel is that the oil is biodegradable and that the toxicity to people and environment is low. It is reported to release fewer solid particles than conventional diesel and it contains no sulphur. It is also important that the generation of $\mathrm{CO}_{2}$ is low as for all the other biofuels as well. Biodiesel is produced in many European countries where the Czech Republic and Germany are leading. In Malaysia and South Africa, synthetic liquid diesel fuels are produced from either coal or natural gas using the FischerTropsch synthesis.

\subsection{Bio-oil}

Pyrolysis is thermal decomposition occurring in the absence of oxygen. The goal of pyrolysis is to produce a liquid fuel, termed bio-oil or pyrolysis oil, which can be used as a fuel for heating or power generation. The properties of pyrolysis oil depend on the process temperature, the period of heating, ambient conditions, the presence of oxygen, water and other gases, and the nature of the feedstock. In general, lower process temperature and longer heating periods result in the production of charcoal, high temperature and longer heating periods increase the biomass conversion to gas, and moderate temperature and short heating periods are optimum for producing liquids. The main benefit of the pyrolysis process, when 
compared to combustion and gasification, is that a liquid fuel is easier to transport then either solid or gaseous fuels. This also means that the pyrolysis plant doesn't have to be located near the end-use point of the bio-oil, but can instead be located near the biomass resource supply, which results in considerably lowering of the fuel transportation costs.

\subsection{Firewood}

The roundwood balance is the difference between net annual increment in the forests and felling (Table 1). The roundwood balance in European countries, including the Nordic and Baltic countries, has been mostly positive the last 50 years suggesting that an increasing amount of wood has accumulated in the forests, which could be used for industrial and energy purposes. In the Nordic countries, industrial woody residues are used to a large extent. In the Baltic countries, however, woody residues from industrial processes are not utilised to their full potential. The use of forest resources for firewood on the other hand, is common both in Nordic and Baltic countries. Also, logging residues after final felling are left to some extent in all countries, except in Sweden and Finland. Another source is logging residues from regeneration cuttings and first and intermediate thinning. In the Nordic countries these are often taken care of but in the Baltic countries this raw material is often unused and it presents a large potential if it is used more intensively for energy purposes. Generally, a high degree of mechanisation is characteristic for the Nordic countries whereas most of the felling operations are performed manually in the Baltic countries. Today, roundwood for energy production is imported from the Baltic countries to the Nordic countries (10-20 TWh/year).

\subsection{Forest chips}

Forest chips are mostly produced from felling residues, felling of broadleaved species and whole-tree harvesting in first thinnings (from sawmill residues in Latvia). The material is chipped into small bits of 1-5 $\mathrm{cm}$. Chipping most often takes place directly in the forest into a truck's container when performing harvest and thinning operations. Chips often have rather high moisture content of $20-50 \%$. Forest chips as well as pellets facilitate automated handling and automatic operation as opposed to timber. 
Table 1. Growing stock $\left(1000 \mathrm{~m}^{3}\right)$ and roundwood balance (million $\mathrm{m}^{3} / y e a r$ incl. bark) for the Nordic and Baltic countries.

\begin{tabular}{lrrrrrr}
\hline Country & $\begin{array}{r}\text { Growing } \\
\text { stock } \\
\text { Coniferous }\end{array}$ & $\begin{array}{r}\text { Growing } \\
\text { stock } \\
\text { Deciduous }\end{array}$ & $\begin{array}{r}\text { Growing } \\
\text { stock } \\
\text { Total }\end{array}$ & $\begin{array}{r}\text { Roundwood } \\
\text { balance } \\
\text { Coniferous }\end{array}$ & $\begin{array}{r}\text { Roundwood } \\
\text { balance } \\
\text { Deciduous }\end{array}$ & $\begin{array}{r}\text { Roundwood } \\
\text { balance } \\
\text { Total }\end{array}$ \\
\hline Latvia & 337 & 236 & 573 & 2.81 & 1.67 & 5.50 \\
Lithuania & 186 & 128 & 314 & 1.86 & 1.41 & 3.27 \\
Estonia & 238 & 214 & 452 & -3.90 & 0.30 & -3.60 \\
NW Russia & 6400 & 2019 & 8419 & 30.16 & 24.94 & 54.10 \\
Norway & 653 & 194 & 847 & 10.00 & 4.00 & 14.00 \\
Sweden & 2189 & 378 & 2567 & 14.24 & 5.08 & 19.32 \\
Finland & 1529 & 338 & 1867 & 13.15 & 5.02 & 18.17 \\
Denmark & 31 & 23 & 54 & 0.73 & 0.27 & 1.00 \\
\hline
\end{tabular}

Note: Most data are after Karjalainen et al. (2004). Changes in the Latvian data are made after details given by Aija Budreiko. Likewise, Changes in the Estonian data are made after details given by Henn Pärn.

${ }^{1}$ Forests under management of the Ministry of Natural Resources. The roundwood balance is the difference between the annual allowable and the actual cuts in Russia.

2 The numbers include all forest, not only productive forest.

\subsection{Pellets}

Pellets are produced by compressing dry pulverised biomass, usually cutter shavings or sawdust from wood industry residues (recycled wood waste) in special pellet factories. They are small cylindrical bits with a diameter of less than $2.5 \mathrm{~cm}$. Pellets have moisture content of less than $10 \%$, much higher energy density than forest chips, and they are far more homogenous. Transporting the fuel is therefore more economic and convenient. Small scale pellet heating is efficient and comfortable and it requires less work and attention than traditional firewood. Large-scale equipment is often less sensitive to the quality of pellets while small-scale equipment needs pellets of high quality (low ash content and high abrasion resistance).

\subsection{Short Rotation (SR) willow and poplar}

SR willow and poplar, also called coppice (SRC) generates a harvest within every three to five years when harvested new shoots grow out from the stumps. For 30 years the culture can be cost-effective. Improved plant material has caused harvests to produce 7-11 tons of dry substance per year. Earlier plant material only produced c. $4-5$ tons of dry substance per year. SRC plantations can reach heights of $6-8 \mathrm{~m}$ before harvest takes place. Harvest is performed with special harvesters and SRC is chipped into chips, which have moisture content of about $50 \%$. Nutrients bound in leaves stays in the field since SRC shed their foliage before harvest. SRC is considered environmentally friendly since no insecticides and fungicides are used and only a few herbicide treatments are necessary during the total crop cycle. Also, when the cultivation of perennial energy crops is substituting annual crops the risk of nitrate leaching will decrease since the soil is plant covered all through the year. It has been observed 
that SRC is good at taking up cadmium from the soil. In Sweden, the R\&D efforts have been intensive and well funded since the 1970s and as a result commercial plantations have been established.

\subsection{Reed canary grass (RCG)}

In the northern parts of the region this energy crop will be interesting since the costs for establishment is low as the crop is sown and it can be grown on most soil types, however best on organic soils. RCG is a perennial grass, which produces about 7 tons of dry substance per year in approximately 10 years. In the spring when RCG is harvested it is dry and very nutrient-poor since RCG moves nutrients from the leaves to the roots before wintertime. Therefore, little nutrients are removed from the area during harvest. Also, transport and storage is optimised when the grass is dry. An advantage is that it keeps the landscape open since it only becomes c. $2 \mathrm{~m}$ high. RCG is very competitive to weeds and there are no requirements for special machinery in the handling of the crop. RCG has been grown in Sweden and Finland. RCG gives the farmer freedom to fast change back to conventional crops.

\subsection{Grain and straw}

The production of cereals for combustion or for fermentation may be grown and harvested in the same manor as for food and fodder. Energy grain production can, however, easily be implemented in agriculture and high and stable yields can be expected and delivered with short notice. The most suitable grain for burning is oats (high energy content). Like pellets, grain is easy to handle. Straw for energy is harvested as when used for fodder. The lowest energy consumption is reached when grain and straw is harvested and pressed together. Straw is often pressed into big bales of $500 \mathrm{~kg}$. The transport costs of these bales are high, which causes only little international trade of straw. However, international trade of straw will probably become a fact when the technology of straw pellets becomes well developed. So far, the burning of straw pellets seems to function well. The use of straw for combustion is well established in e.g. Denmark.

\subsection{Peat}

Peat is an accumulation of more or less decomposed plants that grow in wetlands. In Sweden and Finland, peat is considered to be a slowly renewable fuel based on biomass. However, EU considers it to be a fossil 
fuel when calculating greenhouse gas emissions. The building of peat is a continuous biological process. High ground water, soils retaining water or lakes that pile up create the possibilities for the growth of peat.

In Sweden for example, about 10 million ha of the land surface is covered with peat, which corresponds to almost $25 \%$ of the land surface. Only $0,1 \%$ or 10,000 ha of this area is used for energy peat production. The small amount of peat used for energy is however of great local and regional importance for employment in rural areas and an excellent complementto woodfuels. The combined use of wood- and peatfuels gives advantages for the burners and boilers fired with these fuels. Peat as a local fuel corresponds with the Green paper "Towards a European strategy for the security of energy supply” (European Commission, 2002).

The peatlands need to be ditched before peat production and harvest can start and raw peat contains 90-95\% water. By ditching together with drying in the sun and by the wind the moisture content will decrease to $35-50 \%$ before delivery. Peat is used as milled or sod peat, or can be pressed to pellets or briquettes. Trade of peat pellets has increased during the last years in the Baltic area. In 2004, about 5.4 PJ of peat briquettes was imported into Sweden from Estonia and Belarus. 



\section{Current status on bioenergy in the Nordic-Baltic-NW Russian region}

The data in Table 2, 3, and 4 supply an overall picture on the production of different kinds of bioenergy in the Nordic and Baltic region. Following the individual countries present their status.

Table 2. Yearly production of solid biofuels $(\mathrm{PJ})$ for energy purposes in the 8 countries.

\begin{tabular}{|c|c|c|c|c|c|c|c|c|}
\hline & Firewood & Pellets & Chips & $\begin{array}{l}\text { Forest } \\
\text { industry } \\
\text { residues }\end{array}$ & $\begin{array}{r}\text { Straw \& } \\
\text { grain }\end{array}$ & $\begin{array}{r}\text { SR willow \& } \\
\text { poplar }\end{array}$ & Oilseed rape & Waste \\
\hline Latvia $^{5}$ & 1.53 & 0.02 & 2.55 & & 0.10 & & & \\
\hline Lithuania & 0.19 & & 2.69 & 1.00 & 0.04 & & & \\
\hline Estonia $^{2}$ & 14.81 & 3.68 & 5.68 & & & & & \\
\hline NW Russia & 392.40 & & & 133.20 & 208.80 & & & \\
\hline Norway & 23.40 & 0.72 & 0.36 & 25.56 & 0.36 & 0 & Some & 5.04 \\
\hline Sweden $^{3}$ & 44.64 & 19.80 & 69.12 & 45.00 & & 15,000 ha & 4,500 ha & 24.84 \\
\hline Finland $^{4}$ & 48.00 & 0.32 & 12.38 & 81.00 & 0.40 & & & 3.80 \\
\hline Denmark $^{1}$ & 11.30 & 7.00 & 4.10 & 10.40 & 15.70 & 843 ha & 19,973 ha & 33.50 \\
\hline In total & 536.27 & 31.54 & 96.88 & 296.16 & 225.40 & 15,843 ha & 24,473 ha & 67.18 \\
\hline
\end{tabular}

${ }^{1}$ Energistyrelsen, Energistatistik 2002.

${ }^{1}$ Statistical Yearbook of Estonia 2002. Chips includes wood waste. Pellets are both pellets and briquettes. Peat $=314.000 \mathrm{t}$ in 2004.

${ }^{3}$ Peat $=12.96 \mathrm{PJ}$. For Oilseed rape $5400 \mathrm{~m}^{3}$ was used as biofuel 2003. The total area for Oilseed rape production is 59,400 ha, while ca 4,500 ha corresponds to the production of ca $5,400 \mathrm{~m}^{3}$ for biofuel purposes.

${ }^{4}$ Data from 2003

${ }^{5}$ Briquettes: Use $5.4^{\star} 10^{-4} \mathrm{PJ}$ heat use and $4.7^{\star} 10^{-4} \mathrm{PJ}$ produced energy value

Table 3. Yearly production of liquid biofuels $(\mathrm{PJ})$ for energy purposes in the 8 countries.

\begin{tabular}{|c|c|c|c|c|c|c|c|}
\hline & Ethanol & Methanol & $\begin{array}{r}\text { Methane } \\
\text { (biogas) }\end{array}$ & Biodiesel & Hydrogen & $\begin{array}{l}\text { Black } \\
\text { liquor }\end{array}$ & Tall Oil \\
\hline Latvia & & & 0.08 & & & & \\
\hline Lithuania & 0.05 & & 0.08 & 2,200 tons rape oil & & & \\
\hline \multicolumn{8}{|l|}{ Estonia } \\
\hline NW Russia & & & & & & & \\
\hline Norway & 0.44 & & 0.18 & Some & & & \\
\hline Sweden & 1.36 & & 5.04 & & & 127.08 & 12.24 \\
\hline Finland & & & 1.6 & 0.165 & & & \\
\hline Denmark $^{1}$ & & & 12.24 & & & & \\
\hline In total & 1.85 & & 19.22 & & & & \\
\hline
\end{tabular}

${ }^{1}$ Energistyrelsen, Energistatistik 2002. 
Table 4. Energy production from biomass as a percentage of the total energy consumption. (Peat is included in Sweden and Finland).

\begin{tabular}{lrrr}
\hline & $\begin{array}{r}\text { Energy production from } \\
\text { biomass } \\
\text { (PJ) }\end{array}$ & $\begin{array}{r}\text { Total energy } \\
\text { consumption } \\
\text { (PJ) }\end{array}$ & $\begin{array}{r}\text { Biomass production in } \\
\text { \% of total consumption }\end{array}$ \\
\hline Latvia (heat) & $?$ & 34.9 & $?$ \\
Lithuania & 28.3 & 376.2 & 7.5 \\
Estonia & 24.0 & 130.0 & 10.3 \\
NW Russia & $?$ & $3,370.0$ & 0.3 \\
Norway & 59.4 & 792.0 & 7.5 \\
Sweden & 370.8 & $1,461.6$ & 25.4 \\
Finland & 394 & $1,475.0$ & 26.7 \\
Denmark & 85.4 & 829.0 & 5 \\
\hline
\end{tabular}

\subsection{Latvia}

Wood is the most important local bioenergy resource in Latvia both by volume and by usage. The firewood has been used in comparatively equal shares in all regions of Latvia. Firewood has a solid position in the energy balance and its proportion in the producing of heat is growing. Considering the balance of primary heat energy (apart from the primary electricity), the proportion of wood considerably increases and consistently exceeds $30 \%$. Analysing the consumption of wood for production of energy by sectors, the remarkable share of household consumption that exceeds $50 \%$ is explicitly marked out. The use of wood briquettes and pellets in the heating of individual houses is gradually increasing.

\subsection{Lithuania}

Energy produced from biomass is about $7 \%$. Recourses of domestic fuels are: $60 \%$ wood fuels, peat contributes with c. $35 \%$, whereas straw and biogas only contribute with c. $1 \%$. Biofuels are used in space heating as firewood for heating of individual houses, woodchips, and sawdust from industry in centralized district heating (forest chips are used in a very small scale). The total installed capacity of boilers is approximately 370 MW, where the biggest is approximately 10MW. Short rotation energy wood is being introduced to the market (approximately 100 ha of Salix L.). The authorities support establishment of plantations. The initial costs of establishing plantations are compensated to the owner. The production and consumption of biodiesel and bioethanol is very low. There are no installations to generate electricity from biofuels as of yet. Operation of the first such will start September 2005. 


\subsection{Estonia}

The energy production in Estonia relies mostly on domestic oil shale. The total production of primary energy amounted to $152 \mathrm{PJ}$ in 2004. From this $18.3 \%$ relies on renewable bio-fuels. The bio-fuels are domestic and consist of wood (mainly firewood, logging residues, waste from forest industries, wood pellets and briquettes at a lesser rate) and peat fuels (peat briquettes). The consumption of wood fuel was $33.39 \mathrm{PJ}$ and the peat production 314 thousand tons in 2004. Because the wood prices are relatively high on the Scandinavian markets firewood is exported as commercial wood and forest chips causing temporary shortages of wood resources in local heating plants.

During the last decade of the previous century the area of abandoned agricultural lands increased significantly consisting at the present time of about 300,000 ha. On arable lands, the cultivation of energy forests is a promising alternative. On some experimental plantations the scientific investigations are still going on. The lack of modern harvesting technology in Estonia and high transportation costs prevent the establishment of plantations of energy forests and intensive exploitation of existing brushwood of grey alder and willows for energy production.

\subsection{NW Russia}

Biomass resources in the European part of Russia have been estimated to be 1440 PJ per year:

1. $954 \mathrm{PJ}$ per year of unused wood that potentially could be taken from forests and used i.e. as forest chips for heating

2. $392 \mathrm{PJ}$ per year that is already used as firewood

3. 209 PJ per year of agricultural residues, including straw and residues already used for energy purposes today

4. 133 PJ per year of surplus wood residues from wood industries.

In Northwest Russia, residues from sawmills and the pulp and paper industry could supply as much as $162-180 \mathrm{PJ} / \mathrm{yr}$ in the oblasts Murmansk, Arkhangelsk, Kerelai, Volodga, Komi, Pskov, Novgrad and Leningrad.

In Russia's Northwest regions, the forestry and pulp and paper industries are very important. The Northwest produces $60 \%$ of the country's paper, and the industry are big potential users of biofuels and suppliers of biomass to power generation companies and to local utilities. The pulp and paper industry in Russia relies on biofuels to meet only some $20-30 \%$ of its energy needs (Europe: $52 \%$ ). 


\subsection{Norway}

Bioenergy amounts to around 7\% of the total energy consumption. About half of the consumption is as wood in households and the other half is wood waste and black liquors from the forest industry. The last years a commercial market for small and medium sized biomass heating facilities has developed and the market for pellets and briquettes is also steadily growing. But still the commercial part (which enters the market, apart from fuel wood) of the bioenergy sector is less than 3.6 PJ.

\subsection{Sweden}

The total use of bioenergy in Sweden has doubled from 180 to more than $360 \mathrm{PJ}$ in the last 20 years (Figure 1). A large proportion of this growth comes from the district heating sector, which used more than 126 PJ of biofuels in 2003. The largest user is still the industry (mainly pulping and sawmilling industries) which used almost 180 PJ of biofuels in 2003. More than $36 \mathrm{PJ}$ is used directly for heating.

Sweden uses energy taxes, which discriminate the use of certain energy carriers. Carbon dioxide tax, sulphur tax and energy tax on electricity all increases the competitiveness of biofuels. In total, these energy taxes generated about 6.7 billion EUR in 2003, which corresponds to $10.2 \%$ of the total Swedish tax revenues. Since 2003, a system with green certificates for electricity from renewable sources has led to a boost in investments in especially bio-power (electricity from biofuels) in CHP plants and pulping industries. Therefore, bio-power production will double from 2002 to 2010.

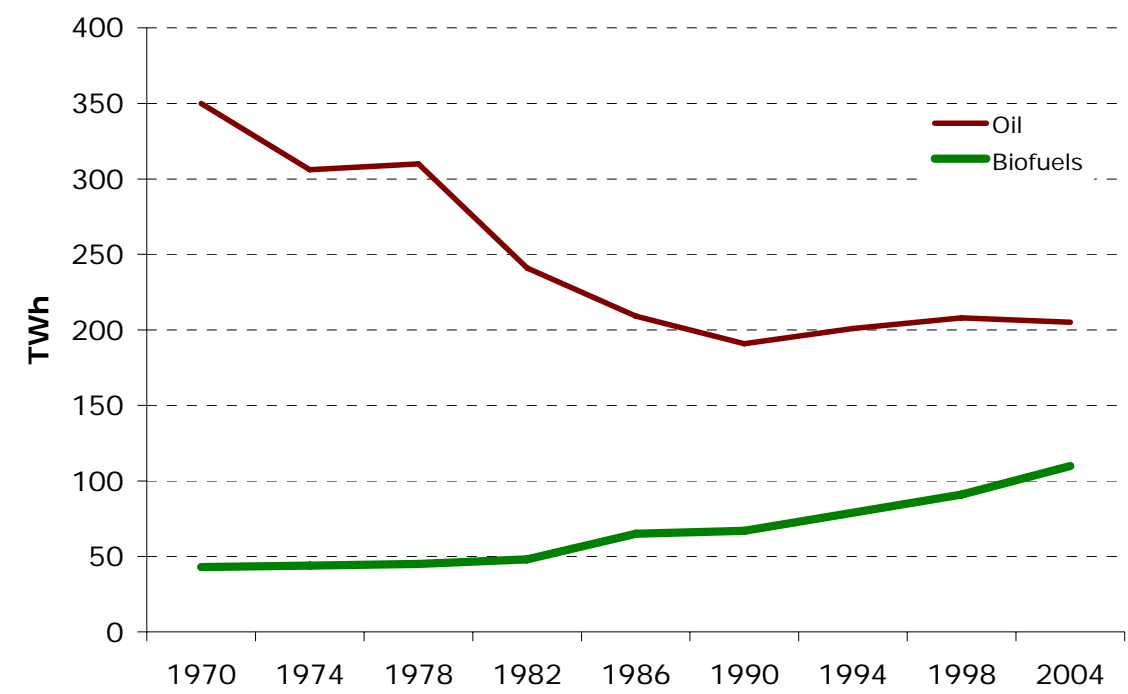

Figure 1. Oil and biofuel supply in Sweden 1970-2004 in TWh (1 TWh = 3.6 PJ). Based on: Energy in Sweden 2004, Swedish National Energy Agency. 
In Sweden, the bioenergy sector is totally dominated by fuels originating from the forests. The forest industries produce large amounts of byproducts (black liquor, bark, chips, sawdust, tall oil) and the harvesting operations in the forests produce harvesting residues and roundwood of low industrial interest. By-products from forestry operations are presently used at a level of around 10 TWh per year, but the amount is increasing. There is a potential for a large increase in the utilisation of this segment.

In table 5, the gross potential includes all branches and needles from forestry operations. The net potential assumes that harvesting residues are taken out once per forest generation and that $75 \%$ of the needles and $25 \%$ of the branches are left on the forest floor. It is possible to remove harvesting residues more than once per forest generation, but then it is recommended to compensate for nutrient losses by ash recycling.

The use of pellets has grown from almost 8.6 PJ (0.5 Mtons) in 1997 to 21.6 PJ (1.25 Mtons) in 2004, of which the small scale (household) sector today uses $35 \%$ (Table 6).

Table 5. Annual potential for harvesting residues in Swedish forests 2010-2019 (PJ)

\begin{tabular}{lrr} 
& Gross potential & Net potential \\
\hline First thinnings & 36.00 & \\
Intermediate thinnings & 51.12 & \\
Regeneration fellings & 181.44 & \multirow{2}{*}{117.72} \\
Total & 268.20 & \\
\hline
\end{tabular}

Source: SKA 99 - Report no. 2, Swedish National Board of Forestry, 2000.

Table 6. Development of the Swedish pellet market 1998-2004 (PJ)

\begin{tabular}{lrr}
\hline Year & Swedish market & \% small scale \\
\hline 1998 & 9.38 & 11 \\
2000 & 12.01 & 12 \\
2002 & 15.79 & 26 \\
2004 & 21.96 & 35 \\
\hline
\end{tabular}

Source: Pelletsindustrins Riksförbund, 2004.

In the transport sector, renewable motor fuels corresponded to $1.1 \%$ of the energy use in the transport sector in 2003. 3.6 PJ of bioethanol was used in 2003, mainly as low admixture (ca 5\%) in existing motor fuels. This method requires no modification of older engines or expansion of existing distribution infrastructure. On the other hand, low admixture of bioethanol can reduce incentives for development and investments in new vehicle technologies. Sweden is advancing fast in the production of ethanol using cellulosic materials like wood in the production. A pilot project, which started in Örnsköldsvik 2004 is showing the way. Sweden is leading in these areas. RME is also used partly as a low admixture (ca $2 \%$ ) in diesel fuel, but the potential volumes are regarded as small. In 2003 c. $5,500 \mathrm{~m}^{3}$ of RME was used.

Salix (willow) is the energy crop, which is mostly recommended in Sweden. At present, approximately 15,000 ha of agricultural land are 
used but this is expected to improve, as the European Common Agricultural Policy reduces its subsidies, the farmers will be looking for alternative uses of agricultural land. There are further opportunities to increase the use of straw and energy-grasses.

\subsection{Finland}

Bioenergy covers $20 \%$ of the primary energy consumption (294 PJ) and $10 \%$ of the electricity demand (30.6 PJ) in Finland, which are the highest figures within the industrialised countries. Possibilities to increase the total use of bioenergy by $50 \%$ and nearly to double the generation of bioelectricity before 2015 have been identified. The use of peat (not in above figures) was $100 \mathrm{PJ}$ (2003).

Biomass-based fuels have traditionally included residues from the chemical and mechanical forest industry and wood fuels used for heating homes. Forest chips from harvesting residues, straw, perennial energy crops, such as reed canary grass, biogas and recycled fuels have complemented the supply of biomass-based fuels during the last decade. Multifuel operation of boilers and co-firing biomass with coal and peat are preferred in large power plants because the availability of many types of biomass is seasonal and can have significant variations from year to year.

\subsection{Denmark}

The total Danish energy consumption amounted to 829 PJ in 2002. Denmark is leading in the area of using straw for heating and electricity and Denmark has great capacity and knowledge in building straw fired power plants. Also, Denmark is the only country who has developed the technology of using straw pellets. In 1996, approximately 15\% of the Danish harvest of straw was used for energy purposes, which amounted in approximately $16 \mathrm{PJ}$ (Table 7). Likewise, wood has been burned for energy comparable to $22 \mathrm{PJ}$, which is c. $4 \%$ of the total energy consumption in Denmark. At present, the use of willow is small and insignificant compared to other wood sources. The production of methane is mainly based on farmyard manure mixed with approximately $20 \%$ of by-products from industry, which gives a biogas yield of $33 \mathrm{~m}^{3} / \mathrm{m}^{3}$. 
Table 7. The use of biomass (PJ) for energy in Denmark in the period 1980-2002. Energistyrelsen, Energistatistik 2002.

\begin{tabular}{lrrrrrr}
\hline & $\mathbf{1 9 8 0}$ & $\mathbf{1 9 9 0}$ & $\mathbf{1 9 9 5}$ & $\mathbf{2 0 0 0}$ & $\mathbf{2 0 0 1}$ & $\mathbf{2 0 0 2}$ \\
\hline Straw & 7.1 & 14.2 & 13.1 & 12.2 & 13.7 & 15.7 \\
Chips & 0.2 & 1.9 & 2.3 & 3.0 & 3.5 & 4.1 \\
Pellets & 0.1 & 1.7 & 2.4 & 5.1 & 6.5 & 7.0 \\
Firewood & 7.6 & 8.8 & 11.5 & 11.7 & 11.9 & 11.3 \\
Forest industry & 3.8 & 6.2 & 5.7 & 6.9 & 8.6 & 10.4 \\
residues & & & & & & \\
Biogas & 0.2 & 0.7 & 1.7 & 2.9 & 3.0 & 3.4 \\
Waste & 10.6 & 15.2 & 21.6 & 30.5 & 32.4 & 33.5 \\
In total & 29.6 & 48.7 & 58.3 & 72.3 & 79.6 & 85.4 \\
\hline
\end{tabular}

In total, approximately $12 \%$ of the total energy use is supplied by bioenergy. In 1980 this percentage was 3.5. The Danish Government has a policy of afforestation on agricultural land. The afforestation will sustain and increase opportunities for producing energy from wood.

Denmark has prioritised the use of bioenergy crops since 1980. Good experience in the production and in infrastructure has been developed and this is a good platform for further research, development and export of knowledge. Especially, in the areas of straw and biogas Denmark could be one of the leading countries.

1993 the Danish Government agreed to implement an agreement on biomass called "Biomasseaftalen", which asks the district heating to use 1.4 mill. tons of straw and wood corresponding to $20 \mathrm{PJ} /$ year. During 2005 the agreement will be fully applied. Legislative and tax regulations have thus made energy use of existing biomass resources such as straw and forest chips feasible.

The use of liquid biofuels for transportation has not been established in Denmark. However, research in these areas is ongoing. 



\section{Plans for future increased use of bioenergy in the Nordic- Baltic-NW Russian region}

\subsection{Latvia}

The forecast of the consumption of firewood depends on how the regions will manage the transition from the extensive use of firewood to a rational use. Currently, people who are involved in rape cultivation are very active, asking for bigger support from the state, because rape is a source for biofuel and the volume is not enough in Latvia.

\subsection{Lithuania}

Lithuania has several programs to develop and increase the usage of biomass in the energy production to $37 \mathrm{PJ}$ in 2010. The planned capacity of electricity generation from biomass should reach $30 \mathrm{MW}$ in 2010. The planned balance of renewable energy for 2010 is i) wind (2.5\%), ii) biomass (1.7\%), iii) hydro (3.5\%), and iv) solar, geothermal, waste (0.025). This makes a total of $7.7 \%$.

The state has approved of a long-term strategy in order to increase the usage of biomass in electricity generation. The main points of the strategy are:

1. A plant is defined as a biomass plant when biomass and biogases amount to more than $70 \%$

2. The ratio between electrical power and heat power is more than 0.23

3. All electricity produced in a biomass plant will be purchased to the national grid at a fixed price of $20 \mathrm{ct} / \mathrm{kWh}$

4. This guarantee and price is valid until the last of December 2020.

The biggest potential for growths lies in wood fuels (forest residues, short rotation energy wood) and straw. Producers of biofuels aim at the target that plantations of Salix should reach 50,000 ha and 750,000 tons of biomass should be produced there. 


\subsection{Estonia}

The Long-term National Fuel and Energy Sector Development Plan until 2015 sets clear targets for the future. The plan states that the share of renewable energy resources and peat in the energy production should increase by $2 / 3$ by 2010 when compared to 1996 levels. The investments into production of wood fuels and peat products for energy production will be promoted. The establishment of energy forests and exploitation of other forms of biomass for energy production will be decided after socioeconomical and ecological analyses.

The production of biodiesel from oil cultures, such as rape, has started nowadays and will increase with a potential production of 50,000-60,000 tons per year.

\subsection{NW Russia}

According to the development plans of Russia the increase of a share of renewed sources of energy by 2020 should reach 20 millions tons fuel per year. The manufacture of wood pellets could reach 500 thousand tons per year alone in the Northwest region in the area of the Baltic sea. There are plans for the translation of more then 150 boilers for biofuel in the Leningrad area. The problem of manufacture of biogas will be defined by the increase in the amount of chicken plants, removed from sources of power supply. The possible manufacture of biodiesel is difficult to predict at the present moment, however, the technologies of reception are developed on the basis of Russian equipment. The Russian Association of biofuel is planning to develop a local market on the basis of small boiler installations for cottage construction. The experience of sale of similar installations is already present. The problem of standardisation of the quality of biofuel will be decided by the appropriate centres of certification, one of which is the FEC-TEST of Moscow and its branch in St. Petersburg. The Federal Management and its branches in the territory of Northwest of Russia is in charge of questions concerning biofuel.

\subsection{Norway}

A development program to stimulate increased use of bioenergy is established in 2005 (23 mill NOK). A development program for the inland counties has also special focus on bioenergy. Enova SF was established some years ago to handle financial support and knowledge creation concerning organisation and implementation of renewable energy policy. The bioenergy programs of Enova are now under evaluation, but it seems that they have been a success and that they will continue. Norway also has a 
small program to promote liquid biomass fuels. All together this adds up to an expectation that the present growth in bioenergy markets will continue in the years to come. Based on an assumption that prices of fossil fuel and electricity will continue to grow, a recent report concludes that a doubling of the use of bioenergy in 10-15 years is realistic. The resources for such a development are available.

\subsection{Sweden}

Replacing fossil fuels with biofuels is recognised as desirable from several aspects, environmental, economic and security of energy supply. In Sweden, bioenergy use has potential to increase in the heating, electricity and transport sectors.

- Heating. The district heating sector is expected to increase to about 216 PJ in 2010, of which 133 PJ comes from biofuels. In a longer perspective the potential is even higher. In the small and medium scale domestic market, there is a potential for conversion of heating with oil and electricity to pellets. Many homeowners turn to pellets or heat pumps due to high prices on both oil and electricity.

- Electricity. Since 2003 a system with green certificates for electricity from renewable sources has led to a boost in investments in especially biopower in CHP plants and pulping industries. Therefore, biopower production will double from 2002 to 2010.

- Transportation. The National Energy Agency, the National Road Administration and the Environmental Protection Agency have developed a strategy for the introduction of biobased motor fuels. It recommends low admixtures of biobased motor fuels of between 5 and $25 \%$. Fuel companies that together hold over $80 \%$ of the Swedish petrol market, now mix in up to $5 \%$ ethanol in their petrol. The energy tax on ethanol in E85 fuel (85\% ethanol + 15\% petrol) was removed in the beginning of 2003. This means that the cost of using E85 today is lower than the cost of using petrol. The number of pump stations for biofuels is rapidly increasing, which is a prerequisite for many people to decide to invest in a car driven by biofuel. Today, there are more than 200 pump stations for E85 and more than 50 pump stations for RME. Many communities have also chosen to use biogas, derived from both sewage treatment plants and old waste dumps, as fuel for some of their buses.

\subsection{Finland}

The national action plan on renewable energy from 1999 has set targets for the increased use of bioenergy and other renewable energy sources. 
The plan has been included in the national climate strategy in 2001 and the plan was revised in 2003 (Table 8 and Figure 2). The targets were slightly tightened, and bioenergy targets were split for specified types of biomass. The main elements of the new action plan comprised developing new technologies, economic instruments, laws, regulations and agreements, and information and training. In addition to these promotion measures with long experiences, it was also suggested to evaluate new measures such as green certificates and feed-in tariffs under Finnish conditions. The climate and energy strategy is now under revision.

Table 8. Targets for exploiting bioenergy sources in Finland in 2005, 2010 and vision for 2025 according to the proposal of the working group for a revised Action Plan for Renewable Energy.

\begin{tabular}{|c|c|c|c|c|c|c|c|c|}
\hline & 1995 & 2001 & 2005 & 2010 & 2025 & & & \\
\hline Bioenergy by sectors & PJ & PJ & PJ & $\begin{array}{r}\text { Increase } \\
\text { from } \\
2001 \\
\%\end{array}$ & PJ & $\begin{array}{r}\text { Increase } \\
\text { from } 2001 \\
\%\end{array}$ & PJ & $\begin{array}{r}\text { Increase } \\
\text { from } 2001 \\
\%\end{array}$ \\
\hline Industry & 156 & 202 & 215 & 6 & 230 & 14 & 268 & 33 \\
\hline District heating & 8 & 16 & 30 & 88 & 44 & 175 & 61 & 4 \\
\hline Firewood (households) & 45 & 49 & 59 & 21 & 72 & 46 & 76 & 55 \\
\hline Transport & 0 & 0 & 1.4 & & 3.1 & & 9 & \\
\hline Bioenergy total by fuels & 209 & 267 & 305 & 14 & 349 & 31 & 414 & 55 \\
\hline Spent liquors from forest industry ${ }^{1}$ & 109.0 & 133.7 & 143 & 7 & 154 & 15 & 167 & 25 \\
\hline Industrial wood residues & 51.8 & 76.6 & 80 & 4 & 84 & 9 & 92 & 20 \\
\hline $\begin{array}{l}\text { Firewood } \\
\text { (excl. forest chips) }\end{array}$ & 43.7 & 45.8 & 50 & 8 & 54 & 19 & 59 & 28 \\
\hline Forest chips & 3.1 & 9.4 & 22 & 133 & 38 & 4 times & 63 & 7 times \\
\hline $\mathrm{REF}^{2}$ & 0.36 & 1.01 & 5 & 5 times & 10 & 10 times & 10 & 10 times \\
\hline Biogas & 0.65 & 0.75 & 2.3 & 3 times & 4.2 & 6 times & 8 & 11 times \\
\hline Agrobiomass & 0.00 & 0.00 & 0.9 & & 2.1 & & 5 & \\
\hline Liquid biofuels (for transport sector) ${ }^{3}$ & 0.00 & 0.00 & 1.4 & & 3.1 & & 9 & \\
\hline
\end{tabular}

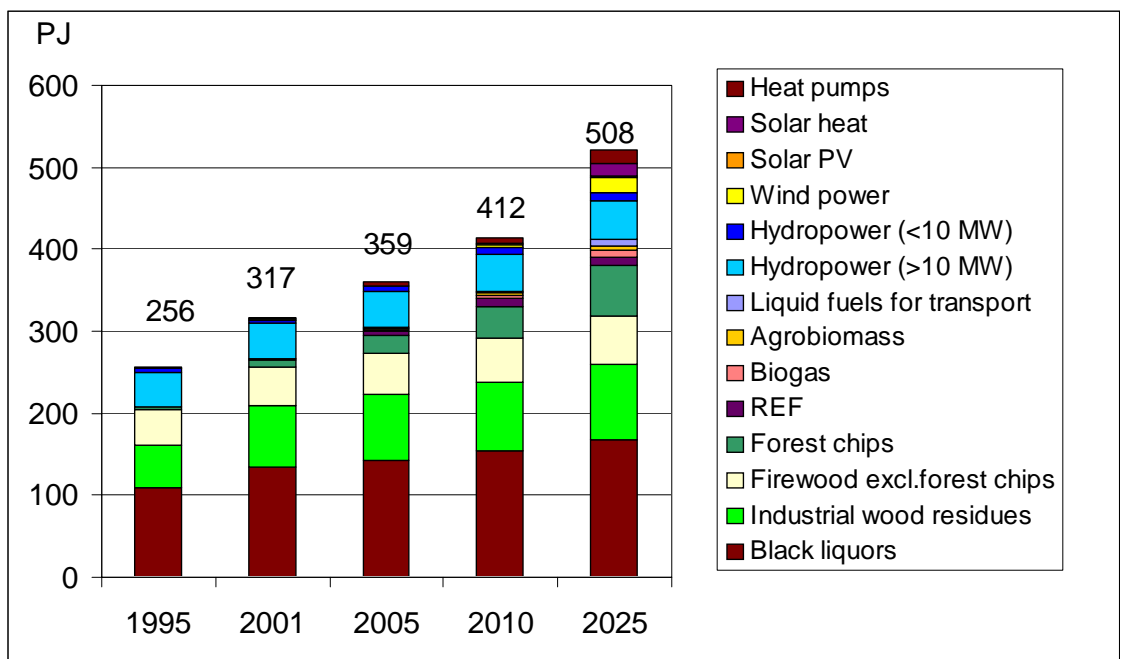

Figure 2. Targets for the use of renewable energy sources in Finland for a revised Action Plan for Renewable Energy. 


\subsection{Denmark}

The biomass agreement in Denmark is supposedly fully implemented during 2005 and 2006. This will increase the use of bioenergy further. Also, the Danish government has signalled that an increased biogas production (from 3.3 to $8 \mathrm{PJ}$ ) is wanted.

The Danish resources that can be used for energy are approximately 160 PJ (Table 9). Roughly half of that are used today. The unused resources are primarily straw and biomass for biogas production (animal waste e.g.). The resources can be increased to a certain point in the future by e.g. planting of energy crops at marginal land and abandoned arable land and by choosing productive crops. Perhaps also sea algae will contribute to the total energy in the future. On the contrary, the resources might become scarcer depending on the tendency to spare large nature areas untouched.

In Denmark, the production of energy crops depends not only on the energy policy, but also on the agricultural policy and the future land use planning. So far, there has been no co-ordination of these policies in Denmark. Not knowing the future policy, farmers are off course reluctant to invest in energy crops. Therefore, Danish farmers and the energy industry needs clear signals on the future intentions on energy crops from the Government.

At the moment there are no tax exemptions or subsidies for liquid biofuels and the future national politics is not yet known. However, a strategy for research and production of liquid fuels are being developed during 2005. The aim is to make the new technologies for production of liquid fuels commercial within 10-15 years.

Table 9. Resources of biomass for energy (PJ) in Denmark.

\begin{tabular}{lrrr}
\hline & Potential & Use 2002 & Percentage used \\
\hline Straw & 55 & 15.7 & 29 \\
Wood & 30 & 28.5 & 95 \\
Biogas & 40 & 3.4 & 8 \\
Waste & 35 & 33.5 & 96 \\
In total & 160 & 81.2 & \\
\hline
\end{tabular}

Energistyrelsen, Energistatistik 2002. 



\section{Barriers, bottlenecks and ways out - in general}

Barriers to the development of the bioenergy sector and a further increased and sustainable use of bioenergy can be divided into three overlapping and interrelated categories. One is connected to the technical development and the technologies used, another is concerned with the economic barriers, and lastly are the barriers connected to the political and institutional decisions. Here, we outline current overall barriers to increased sustainable use of bioenergy and suggest how these may be overcome. Since there is a great deal of difference in how far the different countries in the region have come in the development of different bioenergy techniques, we here describe all barriers in general terms. In the next chapter, we describe barriers that are more connected to the different forms of bioenergy.

\subsection{Technological barriers}

How developed are the technologies? Some are practically untried and rather new and some have been around longer. However, most of them have been in action for only a short time (compared to fossil fuels) since the whole issue of bioenergy is relatively new, when one excludes burning of firewood and combustion technology. Therefore, often a large technological barrier is the lack of confidence and uncertainty over new technologies and their reliability has yet to be fully tested. In the beginning, the risks therefore seem higher than the advantages of the technology. Investments in R\&D are important to develop, test and adapt.

All chains in the supply system, like planting, harvesting, collection, handling and storage are a challenge in the production. In many countries, there is a demand for more demonstration projects to allow for advances in machine development and advances in storage techniques. New technology such as harvesters and balers has to be developed. Bigger series of machinery and equipment and larger volumes of biofuel contribute to reduced production price. The production should be sustainable with a minimum input of chemicals and energy. Therefore, both industry and farmers growing energy crops should reduce energy use in production besides the economic optimisation. Crops that grow with the smallest use of fertilisers and grow well on nutrient-poor sites are preferable.

The use of existing skills or structures in bioenergy production such as machines and forest roads are examples of integration, which will create 
positive complementary effects. Research into how bioenergy handling can be integrated technically into existing systems should be performed. Such integration between different kinds of bioenergy is important and offers possibilities for reduced costs. In this line, integration between the forest industry, farmers, and the energy companies will be beneficial. A set of standards or recommendations, especially designed for the whole industry, could be introduced in order to reduce the transaction costs. Both the supply of biomass and the conversion technologies should be prioritised so that a shortage of biomass feedstock can be prevented once the technologies have been developed.

Households will need good information on alternatives to fossil fuels for heating. Likewise, they need information on alternative fuels and cars. Here, public education campaigns about the biomass sector and its possibilities should be developed in order to raise the public awareness of bioenergy and resolve general misconceptions. Furthermore, the introduction of new technical development to farmers could be a major bottleneck at various regions. Emphasis should therefore be placed on advisory services for farmers when new energy crops are introduced. In large commercial demonstration projects e.g., farmers can get an impression of how energy crop making can be best performed, how to do to make success, and what problems within their area that still needs to be addressed.

Co-combustion could be introduced even further. The advantage of co-combustion is that it offers opportunities to mix biofuels and fossil fuels in an optimised manor. Co-combustion only needs minor modifications to the existing equipment. It has already been introduced and it is well developed in e.g. Denmark, but it needs to be further examined and developed. Therefore, larger and long-term scale tests on co-combustion of energy crops in fossil-fuelled power plants are recommended to evaluate and improve long-term operation. The effectiveness in the use of bioenergy might also be improved for instance through the development of condensation of flue gas from district heating.

A development in infrastructure, especially in the transport sector, is necessary to reduce costs. However, the Nordic countries have good experience in supply infrastructure, which gives a lead over the USA.

Technological barriers can be reduced by investments in R\&D, which lead to improvement of existing systems and introduction of new and improved solutions. As the technology is international, all countries will benefit from domestic R\&D investments. If all countries choose to be free riders and wait for the others to develop technologies, there will be too little investments in bioenergy $R \& D$. One factor which might balance this a bit is that domestic R\&D in many cases also leads to wanted domestic industrial development. We are not aware of any studies of these problems and it will lead too far to discuss this more in detail here. 


\subsection{Economic barriers}

The economic barriers are quite often the most difficult ones to overcome. The main overall economic barrier to bioenergy is that it is simply not cheap enough. However, there might be environmental and other reasons, which are not internalised in the costs. As long as low cost energy is available bioenergy will most probably not develop unless it is subsidised (see below). Many technologies remain too expensive since they can not be produced on a large enough scale until there is a demand for them, and the other way around, there is no demand for them until the costs come down. A negative cycle is evident. A reluctance to take the long-term view if the short-term economics seem unattractive is often seen in market systems. In other words, the markets are thin and this will lead to increased costs.

Existing interests and current energy use (nuclear power, fossil fuel etc.) will therefore have a tremendous effect on the interests in bioenergy. Huge investments in the provision of the various fossil fuels, in their processing, in equipment, as well as in salaries for the large number of people employed in implicated activities will bias the interests. Fossil fuels are often subsidised both directly and indirectly (tax write-offs, preferential research and development support, pricing systems which encourage status quo, direct through a tax). On the other hand, fossil fuels are heavily taxed and it is an empirical question whether these taxes, mostly environmentally motivated, represent the economic costs for the society. Some Swedish economists argue that biomass for energy purposes is subsidised compared with fossil fuels and with alternative use of the biomass. Totally, this represents an economic loss for the Swedish society.

In recent years, cheap imports of biomass have become increasingly available and prices have been pressed down. Domestic biomass must in this way compete with imported biomass, and at the same time with fossil fuel. On purely economic terms domestic biomass is therefore often at a serious disadvantage. Therefore, the use of domestic biomass must offer an additional benefit (factors which are difficult to prize) to compensate for higher prices. This benefit might be the improvement of the greenhouse effect. However, the present prices of fossil fuels are all time high, which favours bioenergy. At the same time, production costs must be reduced and efficiencies improved to bring domestic biomass in favour.

Currently, many countries introduce financial incentives for bioenergy. The promotion of liquid biofuels is now supported by tax exemptions in e.g. Germany, Austria, Spain, France, Italy, UK and Sweden. These subsidies may help the market to develop. Conversely, they may distort the market and lead to a long-term dependency on subvention. In a similar way, subsidies favouring the use of fossil fuels, as mentioned above, intervene in the market. Today, bioethanol is produced without subsidies 
in the United States, which proves that the production is able to become economically sustainable.

In order to get farmers economically interested in growing energy crops their profits must be improved. This can be achieved by several options: cost reduction in energy crop production, fossil fuel taxes, tax exemptions, combined production of biomass for energy and high value plant fractions, and grants for farmers who cultivate energy crops on setaside land. A great problem is the large risks farmers have to take when converting to energy crops. Here, there is a need for a better distribution of risks among the market actors.

The cost of the feedstock is a very important factor for the competitiveness of bioenergy systems. It seems that in those cases where feedstock can be produced as a by-product, the costs are lowest. One good example is biomass from early thinnings and cleanings in Finland. These efforts get state subsidy because they are considered to be important for the future forest of Finland.

\subsection{Institutional and political barriers}

The promotion of the use of bioenergy is increasingly affected by the EU energy policies. Therefore, EU policies are important in the energy policies of the individual member states. However, a key factor in the development of the bioenergy potential is political actions taken by governments. Here, the critical decisions like allocation of R\&D budgets, funding of promotional projects and the policies encouraging the take up and use of bioenergy are very important. Also, trade organisations and other groups try to influence policy according to their program (lobbying).

Apparently, there is no free energy market, but there has been a move towards liberalisation of electricity markets the last decade. Governments have intervened in the past and will do in the future, but international trade agreements will regulate the room for national policy in the future. Most bioenergy markets in the industrialised countries today depend on energy policy support. The political incentives used may be market regulations, R\&D funding, subsidies, taxes and information. Sweden and Finland e.g. has a tradition of energy taxes (carbon dioxide taxes, sulphur taxes). In Norway, the introduction of the "Heat facility subsidy scheme" in 1997 has been crucial for the development of the commercial bioenergy sector. Policy may in this way favour or disfavour bioenergy in competition with other energy forms. Direct subvention is often considered unjust. Government agencies need to aid in the removal of legislative and institutional barriers hindering the widespread introduction of non-conventional energy sources.

Support from policy makers and public opinion makes the introduction of bioenergy business easier. If policy makers are really sure they 
want expansion of bioenergy they should not allow any doubt that this will happen. Doubt will increase the risks involved and be costly. A credible long-term demand for energy crops can be made available through a firm governmental decision, which can not easily be changed. This will help to reassure the investors. This support and decision depends on the general knowledge and awareness about bioenergy systems, which is why successful marketing efforts are needed based on research, which has to be prioritised further. Learning and $\mathrm{R} \& \mathrm{D}$ create a growing market with incentives for more money being spent, and this again triggers more $\mathrm{R} \& \mathrm{D}$ as in a positive loop. In government policies, greater interest is often being put on conversion technologies while the supply of biomass does not receive the same attention. This might lead to lack of biomass once the technology is ready for use as e.g. was seen in the pellet industry in Sweden 2001.

Competition improves innovation and productivity and it is essential for technical development. A way of improving the competitive advantage of bioenergy and boost green technologies is to issue green certificates. Within the past years the green certificate markets have attracted interest in Europe and markets are appearing in many countries. An international green certificate market will ensure that new plants and technologies are established where the highest production potential and the lowest costs are apparent. Import and export of green certificates will ensure that the national targets for renewable energy are reached in the cheapest way. Such a system, however, only supports the most competitive bioenergy technologies presently being most cost effective. Other less developed technologies might be pushed towards the margin with little chance for further development. Additionally, an emission-trading scheme will ensure reductions in $\mathrm{CO}_{2}$ to happen in order to achieve the Kyoto commitments. In this way, the market forces should lead towards energy production, which is considering the environment.

Land use is a key issue in the production of bioenergy crops since the production of energy crops will compete with land used for growing food. Cultivating energy crops on abandoned "set-aside" arable land will be possible but often the soils are not the most suitable for energy crops. 



\section{Barriers, bottlenecks and ways out - specifically}

Looking at each one energy form will show that there are large differences in technology, maturity, organisation and potential for further future use. Also, they experience specific individual barriers and the needs for effective future use differ between them.

\subsection{Bioethanol}

In the Nordic and Baltic countries, special interest would be directed towards the use of wood and agricultural products in the production of ethanol. Here, the production potential is high. The conversion processes from cellulosic material to ethanol have to be improved in a way where they cost less energy and become more effective. The finding of new micro-organisms that easily convert lignocellulose to sugar would be a break through.

\subsection{Hydrogen}

It is essential that i) more efficient and cheaper ways to make hydrogen are developed, ii) needs for and development of cost-effective ways of storing hydrogen are thought of, e.g. new light-weight storage vessels, iii) a comprehensive hydrogen infrastructure (especially in road traffic) has to be developed, iv) fuel cell prices must fall and v) their operating lifetime must be increased. However, in the future exploitation of production of hydrogen from biomass, first changed into sugar and thereafter hydrogen by micro-organisms, is highly interesting.

\subsection{Biogas}

Further increased understanding of the processes and the microorganisms, including knowledge on stress factors and inhabitants, in the production of biogas from manure has great potential in e.g. Denmark where husbandry is large. A co-production of biogas and bioethanol, where by-products from the fermentation to ethanol is used in a further biogas production and fibres from the production of biogas is used together with other energy crops in the production of ethanol, is promising 
with interesting perspectives. Such a co-production would eliminate the disadvantages of separate bioethanol and biogas plants with each their by-products and therefore reduce the cost price.

\subsection{Biodiesel}

The $\mathrm{N}$ fertilisation needed of rape seed crops is high and its environmental sustainability as an energy crop has been questioned.

\subsection{Bio-oil}

Pyrolysis technology, in comparison with combustion and gasification, is in the early state of development and thus the development costs are still very high and not well established. This also means that there is considerable scope for cost reduction. The method is very interesting when considering conversion of municipal trash to bio-liquids. There is even interesting research going on concerning pyrolysis of wood and refining of pyrolysis oil to gasoline.

\subsection{Thermal conversion of biomass to biofuels for transportation}

Solid biomass, like wood residues or waste, can be thermally gasified and cleaned product gas can be processed further for methanol, FischerTropsch-liquids or other types of fuels for traffic. Another alternative is to clean the product gas and feed it to the natural gas network. These alternatives for solid biomass are under research and development and demonstration plants will be constructed about 2010 .

\subsection{Roundwood - Firewood}

Unused amounts of raw material present a large potential if they are used more intensively for energy purposes. Increased use of wood for energy is expected to have a significant impact on the timber and residue markets, as the energy sector is going to be a strong competitor in these markets. This calls for good compromises. In the Baltic countries, the main bottlenecks for a larger use of forest biomass seem to be lack of available and modern technology for harvesting as well as the transportation operations. At the same time, their labour costs are very low, which should allow for intermediate technological solutions. Furthermore, there is a lack of district heating possibilities. The district heating available face 
difficulties because of outdated equipment and large investments are needed in order to update and modernise the production facilities and their capacity. Export of knowledge and expertise from the Nordic to the Baltic countries would help make forest fuel production more efficient and profitable. The potential to increase wood production on abandoned "setaside" arable land is significant. Locally, the increased use of wood energy can have serious environmental impacts. Poor combustion technology in households creates large local pollution. Also, inappropriate transportation of firewood is often taken place and more effective supply chains of firewood are needed. The replacing of natural forests by monoculture energy plantations is a potential threat to existing wetlands and biodiversity. Particular care and strict policies and practices will be required to avoid unfavourable effects and ensure sustainability and health of the forest ecosystem and to avoid the overuse of wood resources. Especially, caution should be made as to avoid excessive nutrient outtake from harvested stands - see below at forest chips.

\subsection{Forest chips}

Intensified research on how to optimise silviculture in order to produce more chipping material is needed. Here, the increase of the level of mechanisation particularly in first and intermediate thinnings is needed. Also, it is essential to understand the nutrient balance and the nutrient outtake associated with intensive chip harvesting of whole trees. Here, for example stands growing on poor soils may experience nutrient imbalances. Another important topic is the return of the increased amounts of wood ash to the forest floor in a way that is harmless to the ecosystem in order to compensate for the outtake of nutrients. Especially, the content of cadmium in return ashes should be studied further to make sure that it does not disturb the ecosystem. Here, more stable ashes are needed. Furthermore, there is a need for better co-operation between energy companies, producers of fuel, producers of ashes, and forest owners on effective return strategies. This co-operation will benefit from standards being drawn on trade of forest chips so that the quality of the products is known.

\subsection{Pellets}

In the case of wood pellets, household consumers have interest in a reliable supply for a stable price. It is therefore essential that a continuous supply of wood residues from forest industry is available for the household market and that the co-ordination with sawmills and secondary wood industries is good. Otherwise, a lack of pellets will occur and the 
availability has earlier been a problem in some countries (Sweden, Finland) causing rising prices and making the market more volatile and less attractive. The equipment (burners, feeding mechanisms, hoppers etc.) has to be improved and even more standardised and convenient in order to reach out to the market of homeowners. The introduction of pellet standards and testing norms for the equipment are two issues that need to be co-ordinated. Homeowners need to be informed and educated in the use of pellets.

\subsection{Short Rotation (SR) willow and poplar}

Introduction to a new crop like SRC, as compared to old farm crops, is a long and expensive process. Also, it appears as a risky business for farmers since the investments made are covering a longer time than annual crops. The conclusions from production in commercial plantations of SRC in Sweden are that good advice to farmers is essential and that a good alignment of interests (perhaps through long-term contracts) between farmers and district heating companies would help to remove many barriers. Also, weed removal techniques need to be more effective and should be further developed. Water availability is frequently the limiting factor and irrigation is often demanded. Good and cheap establishment is necessary for the production capacity and economics. There is also a need for improvement of plant stocks yielding more. The highest yields are observed on organic soils, and fertilisers are essential to reach acceptable yield. However, the need for fertilisers is less than for annual crops. There are good grounds for extra environmental and economic benefits when the growing of SRC is combined with wastewater treatment or sewage sludge deposit. SRC take up nutrients and pollution from the wastewater. These options might generate large extra incomes for the farmer. However, leaching from such fertilised plots should be studied in detail and the quality of sludge must continuously be improved. By choosing plant material that take up cadmium well from the soil one can maximise the uptake and in this way export cadmium from the area. After burning, cadmium can be parted from the ashes and deposited. It therefore seems that more problems can be solved at the same time when growing SRC.

\subsection{Reed canary grass (RCG)}

RCG is too expensive to produce without subsidies on agriculture. Now the cultivation area has reached 6,000 ha in Finland and it is increasing very rapidly. The market needs to be further developed. A possible production of pellets using RCG in combination with wood residues should 
be studied in further detail since this mixture has proved to create a higher quality of the fuel.

\subsection{Grain and straw}

Old farm crops are optimised to give maximum yield. Energy crops should also yield well but here high energy content is also important. Therefore, a great challenge is to create new plant strains with highenergy contents and characteristics to make them suitable as biofuels. Further cost reduction in the production of grain and straw is not likely as the production of both is fully optimised and the knowledge is widespread among farmers. However, whole crop harvesting offers a potential for minor cost reductions. The transport costs has been analysed to decrease if bales of straw are made even bigger $(1,000 \mathrm{~kg})$ or if straw pellets are used instead. In order to minimise the transportation costs, transport between producers and district heating plants should be co-ordinated. Using bigger straw bales will also lead to lower costs of storage. However, the design of today's balers has to be changed.

\subsection{Peat}

Peat suffers from sometimes being treated as a fossil fuel, although it is a slowly renewable biofuel. The political treatment of peat as a fuel is a typical example of a political barrier. For instance, burning peat in a CHP in Sweden gives rise to extra incomes through the green certificate system, but also extra costs through the emission trading system.

Large areas of peat are today ditched and used for forestry and agriculture. These areas leak large amounts of $\mathrm{CO}_{2}$ by themselves through oxidation. Coarse calculations show that these ditched peatlands annually may leak $\mathrm{CO}_{2}$ corresponding to 50-100 TWh annually. In these cases, utilising the peat through combustion will clearly be $\mathrm{CO}_{2}$ neutral. If only $5 \%$ of the ditched peatlands with forest (1.8 million ha in total) would be used, the current Swedish peat consumption (10.8-14.4 PJ/year) could be sustained for 300 years.

Peat is an optimal fuel to improve combustion parameters when cofiring together with high-alkali containing biomass like forest chips or agrobiomass. Peat contains low amounts of sulphur that hinders chlorine layers on hot temperature surfaces and thus decreases corrosion. Peat also decreases fouling and slagging and keeps surfaces of the boiler clean. Peat can be stored for years and its moisture content is stable, so peat can stabilise variations of the quality and availability of other biomass. 



\section{Breaking the barriers - political decisions and strategies}

Technical development and scientific breakthroughs are basic to the development of the bioenergy sector. But political decisions are of prime importance for lifting the area to the full impact on economy and environment. A god example of this dilemma is the renewable electricity production from windmills, without the initial political push and support it would never have broken the barrier.

Looking at the technological barriers it is important to underline that a number of the main technical bottlenecks has already been solved. Biofuels are used on a relatively large commercial scale today for heat and power as well as liquid transportation fuels in the form of ethanol from cereals and diesel from rape seed. Likewise, the possibility of using the whole plant biomass for energy production (lignocellulose) is close to a commercial breakthrough.

As much of the fundamental development research has been done, the technical research now needed should be aimed at improving the economy and energy efficiency of the different processes. How simple this may sound it includes a huge number of areas all of which can be optimised to improve the overall economy and efficiency of the bioenergy sector. At the same time, basic research is needed within a number of scientific areas to secure the development of techniques for utilisation of the full potential of the bioenergy sources.

The main technical issues and areas of research can be found within 4 areas:

1. New and optimised crops for bioenergy. Breeding and optimisation of existing crops as well as development of new varieties and species.

This may include regulation of starch content, protein composition, lignin structures in wood etc.

2. Sustainable and optimised production of biomass for energy. Integrated production systems for biomass, biomass production systems management, optimisation of $\mathrm{CO}_{2}$-capture, life cycle analysis (LCA), analysis and optimisation of conversion techniques, energy flow and nutrient recycling.

3. Primary processing of biomass for energy. Harvesting and logging, wood chips and pellets production, dust, mould and health hazards during biomass processing, pre-treatment to open the biomass, breakdown of biomass to fermentable sugars, disposal of waste 
products (ash) and fundamental work on relation between nano/micro structures and biomass performance/yield.

4. Logistics. Biomass for energy requires an optimised and efficient chain from field/forest to end use to gain competitiveness. The logistic system must cover all steps from harvest, intermediate storage, loading, transport, unloading and storage to ensure the most cost and energy effective all year round supply of biomass.

Bioenergy is therefore no longer in its infancy. It is a juvenile industry, where political decisions on energy policies will have a large effect on the near future commercial exploitation and play an essential role for an increased use of bioenergy. The bioenergy area is at present in the middle of a catch 22 as a full scale technical development must be market driven, but the technology is just below the threshold level where it will attract the large scale investments needed to establish a market. A similar problem is that in some countries the current legislation i.e. taxation or volatile standards may in some cases present an unintentional legislative barrier.

Political support in the form of limited subsidies or mandatory use of bioenergy will therefore have a large positive impact on the creation of a commercial market with committed involvement from the industries. Within the European Union already a mandatory use of 5.75\% biofuels by 2010 has been established, however, even though the overall aim is fixed it is still on a voluntary basis for the individual countries.

Much of the essential knowledge and basic sources for an increased use is present, however, an important question is whether or not the political systems in the Nordic and Baltic region are willing to act? There is an opportunity to build a regional bioenergy/biomass infrastructure on the Nordic-Baltic region. Can this be used as an entry point for the political process ahead?

Political decisions listed in order of impact:

1. Introduction of supportive subsidies

2. Support the build-up of an efficient infrastructure for biomass logistics. Integrate bioenergy with other renewable energy sources

3. Remove legislative barriers

4. Standardise biofuel taxation

5. Secure mandatory use of bioenergy 


\section{Inventions and developments, which created a strong regional position}

The Nordic countries, in particular Finland, Sweden and Denmark, are leading in bioenergy use and technology at the moment. The use of bioenergy has increased in all Nordic and Baltic countries through the last 30 years, and the share of biomass in the total energy production is highest in the world.

\subsection{Research}

In research and development on bioenergy, the Nordic countries are in the forefront. The proportion of research articles from the Nordic countries as opposed to the rest of the world is high. In e.g. the global IEA book on "Bioenergy from Sustainable Forestry", two out of five editors were Nordic and half of the contributors were Nordic researchers. Nordic and Baltic research in bioenergy is supported financially by the Nordic Forest Research Co-operation Committee (www.nordiskskogforskning.org).

\subsection{Standardisation}

Standardisation receives large attention in the European Commission. In the Committee for Standardisation (CEN), the Nordic countries have had large influence. The standards are supposed to enhance trading and use of solid biofuel in Europe. Sweden has had the presidency and Sweden, Finland and Denmark have been represented in all working groups. Many of the 25 standards in 5 different areas build on national standards or research results from Sweden and Finland.

\subsection{Solid biofuels}

Finland and Sweden are technology leaders in the field of feedstock supply technology. Finland, Sweden and Denmark produce over 2/3 of the harvesting machinery for industrial roundwood sold in Europe. Investments in several thousands of additional forest machines are expected, 
when utilisation of forest fuel resources of the EU starts to increase. The Nordic forest machinery manufacturers could conquer this new market.

Nordic manufacturers of large-scale combustion plants for solid biofuels are global front figures. Additionally, Nordic companies are technology leaders in large-scale heat and power plant technology ( $\mathrm{CHP}=$ Combined Heat and Power plant) for wood biofuels. Concerning smaller scale installations, the Nordic countries are competing with the central European manufacturers to reach the market leader's position.

Thermal gasification is a two-step process, in which solid biomass is converted thermo-chemically into a gas. Denmark and Finland are involved in developing methods for biomass gasification. In Finland, demonstration plants are currently being tested.

Denmark is world leading on CHP plants running on straw. All available straw in Denmark is being burnt. Likewise, Denmark is the only country in the world that produces and uses straw pellets as fuel. An example is "Køge Biopillefabrik", which produces 310,000 tons straw pellets per year.

Sweden is leading in the area of short rotation willow and commercial forest fuel plantations. Swedish research and development efforts have been intensive within this area. Good grounds for extra environmental and economic benefits have been observed when growing of willow is combined with wastewater treatment or sewage sludge deposits (bioremediation), since willow take up nutrients and pollutants from the wastewater.

\subsection{Liquid and gaseous fuels}

New biotechnology for processing of straw and wood into liquid biofuels has been developed in the Nordic countries. This includes new and more efficient enzymes, new micro-organisms for fermentation of all plant based sugars and new more efficient processing enabling a much higher capacity for conversion to e.g. ethanol.

Denmark and Sweden have a leading role in the production of biogas on the basis of animal waste and garbage sewage. As an example, 20 biogas plants and 60 farm biogas plants were operated in Denmark 2004. Research is focusing on integrating the bioethanol- and biogas production. This co-production will have a large influence on the economy. 


\section{Good cases and successful examples in the Nordic-Baltic- NW Russian Region}

Information on all aspects is crucial. The positive good cases, which work on a commercial basis in the Nordic-Baltic-NW Russian region, should be highlighted and shown in public. Here, we present some of these cases.

\subsection{Information}

Good advisory service to farmers is essential in order to achieve a change in crops and attitudes. In large commercial demonstration projects, farmers can get an impression of how growing of energy crops can be optimised, how to do to make success, and what problems within their area that still needs to be addressed. In this line, Norway has created "Energigården”, an information centre for bioenergy situated $75 \mathrm{~km}$ north of Oslo (www.energigarden.no). Here, demonstrations are being made of all bioenergy crops. Furthermore, courses and showings are offered.

The creation and operation of societies and associations that participate actively in bioenergy policy, do lobbying, and create public information are of great value. In each of the Nordic countries, such societies have been created: NOBIO in Norway (http://www.nobio.no), DANBIO in Denmark (www.danbio.info), FINBIO in Finland (www.finbio.fi) and SVEBIO in Sweden (www.svebio.se).

Within the EC project RECASH guidelines, course material and demonstrations of recycling of wood ash materials to forest are freely offered on www.recash.info .

\subsection{Solid biofuels}

The supply of energy to the district heating companies in the Nordic countries has changed from mainly oil in the 70'ties to bioenergy today.

The total use of wood pellets in Sweden has gone from 0 TWh in 1993 to 6 TWh in 2003. An increase of $80 \%$ is observed over the last 4 years. Pellets for household heating have gone from 0 TWh in 1993 to 2.2 TWh in 2003, showing an increase of $425 \%$ over the last 4 years. In Finland, an 
increase in the use of forest chips in CHP production during the last five years has also been seen.

\subsection{Liquid and gaseous fuels}

Sweden has a market for cars running on biogas and ethanol. Approximately 2,700 cars and 6-700 heavier vehicles were running on biogas in 2003. Here, the introduction of cars running on ethanol (e85 - 85\% ethanol and $15 \%$ gasoline) has been a success. Many city busses drive on bioethanol. The development has gone from a couple of hundred flexifuel cars (cars that can run on both 'normal' gasoline and on mixtures of ethanol and gasoline) in 2001 and to 16,000 cars (mostly Ford Focus) in 2005. In 2005, Saab and Volvo introduced ethanol flexifuel cars. It is hypothesised that 450,000 cars ( $10 \%$ of total fleet) will be flexifuel cars in 2010. The number of filling stations for both biogas and ethanol are growing rapidly. Also, Sweden has succeeded in blending 5\% ethanol into normal gasoline.

In Sweden, a total region (Västerbotten \& Västernorrland) is mobilised to be running on renewable energy. The vision is to create a worldleading region in the process of implementing a renewable transport system based on biomass. The region should be self sufficient in transport fuels in 2030. Mobilising, engaging and activating people provide the basis for success. A publication is distributed to every household in the region and local meetings are arranged in every municipality.

Year 2001, a large ethanol plant was initiated outside the town of Norrköping in Sweden. Here, $50,000 \mathrm{~m}^{3}$ ethanol is produced from grain every year. In Örnsköldsvik, $15,000 \mathrm{~m}^{3}$ ethanol is produced from pulp industry per year. Also, a large-scale pilot project called "Etanolpiloten" has been initiated May 2004 in order to produce ethanol based on residuals from forestry (cellulose). The pilot project is world leading in this area. Here, the research findings are utilized in a larger scale.

The IBUS plant in Denmark is at present the world's largest process demonstration unit for the production of ethanol based on straw and the organic fraction from household waste. The concept very efficiently integrates solid and liquid biofuels in a power plant based process. The plant was started in May 2005 and the preliminary test results are expected to play a key role in the international development within this area.

At the Technical University of Denmark a 'maxifuel' pilot unit will open June 2006. In this demonstration project, bioethanol, methane and hydrogen are co-produced from wheat straw in one and the same plant. 


\section{Moving the region forward - project proposals}

A countless number of research and development projects can be derived from the previous chapters where barriers for increased use of bioenergy and means of how to break these barriers were described. These former chapters sketch the framework of sound projects that the countries in the Nordic-Baltic-NW Russian Region will benefit from cooperating within. The contents of these chapters will not be repeated here nor will a long list of specific project proposals be presented. However, on the basis of the previously presented arguments, five specific project ideas have been chosen and a short draft project description of these ideas is presented. All project proposals contain important problems that need to be solved in all the countries in the Nordic-Baltic-NW Russian Region.

\subsection{Bio-ash reactivity test}

Aim

To establish a simple, reliable, relatively cheap and practically usable method for measurement of the solubility and reactivity of bio-ash.

\section{Background}

Harvest of forest biomass for heat and energy production may lead to export of nutrients from the forest ecosystem. In a sustainable ecosystem, input and output of nutrients must balance to ensure the fertility of the forest soil. Recirculation of wood ash from energy production to the forest is in focus as a way of counteracting nutrient export.

However, ash application in forests may affect the ecosystem in various ways e.g. alter the chemical composition of the soil, tree needles and leaching soil solution, and chance the composition and biodiversity of the ground flora and fauna. The effect of ash application to forest ecosystems is often linked to the dosage and the chemical composition of the ash, especially the solubility and reactivity. The solubility and reactivity can be manipulated through pre-treatment and hardening of the ash before spreading in the forest and thus the effect of ash application in the forest ecosystem can be limited to a degree that may be considered acceptable. At present, we lack a test that link the limit for acceptable effects from 
ash application on the forest ecosystem with the ash dosage and the chemical properties of the ash, mainly regarding solubility and reactivity.

\section{Method}

Compare the dosage and the chemical properties of ash (mainly solubility and reactivity) with the effects from ash application on the forest ecosystem. Define what is meant by "acceptable effects from ash application on the forest ecosystem". Finally, the method needs to be simplified, easy to use and relatively cheap to insure that it will be used.

\subsection{A model of biomass for energy}

Aim

To develop a model for optimized supply of biomass for energy from agriculture and forestry.

\section{Background}

The contribution of biomass to the national energy supply could be of much larger scope than it is today. Especially, in relation to the transportation sector, there is an increasing need of replacing fossil fuels by other alternatives. Within agriculture and forestry, there are many alternative ways of cultivating biomass for energy purposes, but at the same time these primary production systems must still supply food, feed and materials as in their present production scenario. However, there is a large unrealized potential for optimizing the supply of biomass for energy through an adapted agricultural practice.

\section{Method}

The project should provide a coherent analysis involving the selection of crops and cultivation systems including both current agricultural practice and an agricultural practice adapted for energy production. This is combined with an integration of biomass in the energy system and the selection of an optimum form of transportation. 


\subsection{Bioenergy land}

Aim

To develop a model that can predict how the decisions for usage of bioenergy will affect the land use and the landscape.

\section{Background}

The increased use of biomass from forestry and agriculture for energy production affects the decisions concerning land usage and thereby the landscape. The increased concern in EU, for lowering of the financial support to the agricultural production will also play an important role for the forming of the landscape. Currently politicians, decision makers and other administrators lack a model predicting how the decisions for usage of bioenergy will affect the land use and the landscape.

\section{Method}

A model that by the use of GPS can predict how the decisions concerning the usage of bioenergy will affect the land use and the landscape should be developed on the basis of calculation of various scenarios for biofuel prizes, agricultural production prizes and knowledge concerning the linkages between these prizes and the utilisation of the land.

\subsection{Bioenergy health}

\section{Aim}

To avoid injuries from the unhealthy working conditions that often occur in the surroundings of wood chips production and wood chips handling.

\section{Background}

Production and handling of wood chips imply a serious health risk for the workers involved. In Sweden, 70\% of the machine workers suffer from lung dysfunctions. We know that there may most likely be a linkage between the mould spore density in the air, the storage time and the storage conditions. However, knowledge of these linkages is currently lacking.

\section{Method}

Knowledge on how storage time and conditions affect the growth of the undesirable moulds handling wood chips should increase and become 
widespread. The concentration of the mould spores should be counted under various controlled and well defined storage conditions and storage periods. Counting the concentration of air born mould spores should be done under natural conditions and under artificial conditions where the spores are blown out of the material using a rotating spore separating tube.

\subsection{Bioenergy information}

\section{Aim}

To increase the knowledge and awareness of bioenergy matters at all levels in the Nordic-Baltic-NV Russian Region

\section{Background}

At the seminar, everybody agreed that information and highlighting of successful cases were strong tools in breaking the barriers, increasing a positive attitude and finally increasing the use of bioenergy.

The SNS information network under the Nordic Council of Ministers (www.program.forskningsradet.no/sns/en/index.html) is preparing a website to co-ordinate promotion of research results in Nordic-Baltic forest research. Highlighting the theme of bioenergy on the web site through a special campaign is possible if funding can be provided.

\section{Method}

It is important that information reaches as many as possible as fast as possible including all kinds of people interested in bioenergy, e.g. politicians, managers, researchers, power and heating plant workers and administrators. Therefore, the information on research projects, results and conclusions should be available at various levels regarding both text length and degree of specialisation. The information should be accessible in all levels from popular story style to scientific extended version. Besides bringing forward good examples and successful cases, the bioenergy-theme should ensure better contact between actors within the field of bioenergy and the common press. Furthermore, the website should provide the natural basis for promotion of networking and exchange of knowledge between researchers. 


\section{Concluding remarks}

Countries within the Nordic-Baltic-NW Russian region are presently at different stages in their development in the field of renewable energy. There is reason for optimism since plenty of biomass resources for use in the energy supply are still available and technology development is progressing in this region.

A co-ordinated effort is necessary for obtaining a valuable bioenergymarket, finding the necessary resources and identifying the framework conditions, which makes it possible to develop processes and progress. It is desirable to concentrate on more than one renewable energy form in the long-term transition towards sustainable energy systems since the competition between different sources and technologies will cause the transition to move more smoothly and cost effectively. However, for competition to be effective the bioenergy alternatives need to be mature and well established.

Around the Nordic-Baltic-NW Russian region, different needs and priorities will influence the balance of concern between energy provision and environmental protection. The large number of networks, which reflects the diversity of the groups of interest, embracing technology, biology, economics, etc., is typical for bioenergy. An optimal exploitation of bioenergy requires joint solutions based on a diversity of professional knowledge (industry, agriculture and research), often in collaboration with and sometimes in competition with other industries that use the same biomass as raw material.

The time needed to achieve substantial change and accelerated development in bioenergy will be long and the pace will be slow. Overoptimistic views on the speed of technological change are widespread. The necessary build-up of knowledge will in all probability take many decades and even longer unless determined efforts are made to eliminate existing barriers and accelerate the speed of development.

Barriers to an increased sustainable use of bioenergy in the future are often effects of poor market governance. The barriers could possibly be broken if deliberate efforts are made to align interests and incentives of different actors towards the overall aim of increasing bioenergy use. The weight that politicians choose to put on issues like climate change, land use, independency of the fossil fuel supply and environmental quality is important for the future use of bioenergy. An increased investment in long-term sustainable energy caused by well-thought-through political means of navigation will create possibilities for further expansion in the bioenergy sector. 



\section{Resumé}

Forbruget af energi er steget mere end 20\% i Europa siden 1985. Vedvarende energikilder, som er $\mathrm{CO}_{2}$-neutrale, bliver vigtigere I fremtiden og her er bioenergi en af de væsentligste kilder i en bæredygtig energiforsyning. På verdensplan yder bioenergiproduktionen kun et beskedent bidrag til energibalancerne og området modtager kun en beskeden andel af forsknings- og udviklingsmidler. Produktionen af bioenergi er således en ung, spirende industri, hvor dog en del af de væsentligste tekniske barrierer allerede er løst.

I de nordiske og baltiske lande dækker skovene en stor procentdel (ca. $50 \%$ ) af det totale areal. Alligevel udgør skovene en stor uudnyttet energiressource. De nordiske lande har desuden en lang og stærk tradition for landbrugsproduktion af afgrøder. EU's jordbrugspolitik, som opfordrer bønderne til at lade jorden ligge brak, forårsager en tilgang af disponibel jord, hvor der i stedet kan dyrkes energiafgrøder eller rejses skov med sigte på en forøget produktion af bioenergi. De nordiske og baltiske lande har et naturligt udvalg af biomassetyper som kan benyttes til produktion af bioenergi og det er positivt at der fortsat er store tilgængelige biomasseressourcer. Den tekniske udvikling på området gør også fremskridt i regionen.

På den anden side er der stadig mange barrierer for en øget og bæredygtig produktion og anvendelse af bioenergi i regionen. Samarbejde mellem områdets faglige discipliner samt en koordineret indsats fra politikere og embedsmænd er nogle af de nøgler der kan åbne dørene for en øget anvendelse af bioenergi. I denne sammenhæng spiller det en afgørende rolle, at politikerne vægter emner som klimaændring, arealanvendelse, uafhængighed af fossile brændsler og miljøkvalitet tungt. Politisk støtte i form af indføring af statstilskud, fjernelse af lovgivende barrierer og sikring af obligatorisk forbrug af bioenergi vil påvirke forbruget og opbygningen af bioenergimarkedet positivt.

Denne rapport beskriver mulige bioenergiafgrøder og brændsler/brændstoffer i den nordiske, baltiske og nordvestrussiske region (Letland, Litauen, Estland, NV Rusland, Norge, Sverige, Finland og Danmark) og analyserer status og det nuværende forbrug af bioenergi samt de fremtidige planer for forbruget i regionen. Rapporten identificerer barrierer for vækst på bioenergimarkedet samt beskriver egnede foranstaltninger og løsningsforslag til at overvinde barriererne for tiltagende bæredygtigt forbrug af bioenergi i hele regionen. Der fokuseres specielt på nødvendige politiske beslutninger og strategier for at bryde barriererne og fortsætte fremdriften. Endelig betoner rapporten den positive effekt som tidligere succeshistorier har, identificerer eksisterende udvikling og op- 
findelser på området som bidrager til regionens stærke position i verden samt præsenterer konkrete projektforslag, der vil hjælpe til fortsat udvikling af bioenergiområdet i regionen. 


\section{References}

This paper is based on the following references:

Boyle, S. (1994). Making a renewable energy future a reality: case studies in successful renewable energy development. Renewable Energy, 5: 1322-1333.

Charters, W.W.S. (2001). Developing markets for renewable energy technologies. Renewable Energy, 22: 217-222.

EU Commission (2002). Final report on the the Green Paper "Towards a European strategy for the security of energy supply"

Homepage of IEA Bioenergy.

http://www.aboutbioenergy.info/technol ogies_pyrolysis.html

Homepage of Wikipedia, The Free Encyclopedia. http://en.wikipedia. org/wiki/Thermal_depolymerization

Jefferson, M. (1994). Global prospects for renewable energy. Renewable Energy, 5: 5-11.

Karjalainen, T., Asikainen, A., Ilavsky, J., Zamboni, R., Hotari, K.-E. \& Röser, D. (2004). Estimation of energy wood potential in Europe. Working paper of the Finnish Forest Research Institute. www.metla.fi/julkaisut/workingpapers/2 004/mwp006.htm. pp. 1-43.

Krotscheck, C., König, F. \& Obernberger, I. (2000). Ecological assessment of integrated bioenergy systems using the sustainable Process Index. Biomass and Bioenergy, 18: 341-368.

Larsen, H. \& Petersen, L. S. (eds.), Risø energy report 1 . New and emerging technologies - options for the future. Risø-R-1351(EN) (2002) 59 p.

Larsen, H., Kossmann, J. \& Petersen, L. S. (eds.), Risø energy report 2. New and emerging bioenergy technologies. RisøR-1430(EN) (2003) 48 p.

Larsen, H., Feidenhans'l, R., Petersen, L.S. (eds.), Risø energy report 3. Hydrogen and its competitors. Risø-R-1469(EN) (2004) $72 \mathrm{p}$.

Lundmark, R. \& Söderholm, R. 2004. Brännhett om svensk skog. En studie i råvarukonkurrensens ekonomi. SNS Förlag, Stockholm. 204 pp.

Lynd, L.R., Cushman, J.H., Nichols, R.J. \& Wyman, C.E. (1991). Fuel ethanol from cellulosic biomass. Science, 251:1318-1323.

McGowan, F. (1991). Controlling the greenhouse effect. The role of renewables. Energy Policy, March 1991: 110-118.

MoMentum. Bioenergi i brændpunktet. Jord og Viden Tema, nr. 3, 23. September 2004, 35 pp.

PiR - Pelletsindustrins Riksförbund Swedish Association of Pellets Producers (2004).

Radetzki. M., 2004. Svensk energipolitik under tre decennier. En studie i politikermislykkanden. SNS Förlag, Stockholm. 136 pp.

Roos, A., Graham, R.L., Hektor, B. \& Rakos, C. (1999). Critical factors to bioenergy implementation. Biomass and Bioenergy, 17:113-126.

Röser, D., Asikainen, A., Gjølsø, S., Jaskelevicius, B., Johansson, D., Jylhä, P., Kairiukstis, L., Konstantinova, I., Lileng, J., Lunnan, A., Mandre, M., Murmi, J., Pärn, H., Saksa, T., Sikanan, L., Suadicani, K., Toropainen, M. \& Vilkriste, L. (2003). Wood fuel resources and bottlenecks of utilization in Nordic and Baltic countries. The Finnish Forest Research Institute, Joensuu, Finland, Research paper 901, $68 \mathrm{p}$.

Statistical Yearbook of Estonia 2005

Stiftelsen Svensk Torvforskning. (2005). Projektrapport 52, Uthållig och miljövänlig användning av torv - var och hur? SVEBIO - Swedish Bioenergy Association (2003). Fokus Bioenergi, Nr. 1-10, www.svebio.se

Svensk Fjärrvärme. (2004). Fjärrvärme och kraftvärme i framtiden.

Swedish National Energy Agency. (2004). Energy in Sweden 2004.

Swedish National Board of Forestry. (2000). Skogliga KonsekvensAnalyser, SKA 99.

Venendaal, R., Jørgensen, U. \& Foster, C.A. (1997). European energy crops: A Synthesis. Biomass and Bioenergy, 13: 147-185. 



\title{
Appendix 1. List of interesting web sites on bioenergy in the region
}

\author{
SVEBIO - www.svebio.se \\ NOBIO - http://www.nobio.no \\ DANBIO - http://www.danbio.info/DANBIO.htm \\ FINBIO - http://www.finbio.fi/index.asp \\ Latvian Bioenergy Association - www.latbio.lv \\ Bioenergy in Finland - http://www.finbioenergy.fi/default.asp?init=true\&InitID=398;0 \\ European Biomass Association - http://www.aebiom.org/ \\ Foreningen for Danske biogasanlæg - http://www.biogasdk.dk/ \\ IEA Bioenergy - http://www.ieabioenergy.com/ \\ The Bioenergy Network of Excellence - http://www.bioenergynoe.org/ \\ Centre for Biomass Technology - http://www.videncenter.dk/uk/index.htm \\ The Swedish Association of Pellet Producers - \\ http://www.pelletsindustrin.org/page/1/41.html \\ Gasföreningen - http://www.gasforeningen.se/ \\ Energigården - http://www.energigarden.no/ \\ Ministry of Petroleum and Energy, Norway - http://odin.dep.no/oed/english/bn.html \\ Danish Energy Authority - http://www.energistyrelsen.dk/sw11492.asp \\ Swedish Energy Agency - \\ http://www.stem.se/WEB/stemex01Eng.nsf/F_PreGen01?ReadForm \\ Grønn Varme, Norge - http://www.gronnvarme.no/bioenergi.html \\ Nordic Energy Research - http://www.nordicenergy.net/index.cfm?LID=3 \\ Norsk Ved - http://www.norskved.no/ \\ Climate Neutral Gaseous and Liquid Energy Carriers - \\ http://www.gave.novem.nl/novem_new/index.asp?id=1
}

The RecAsh project - http://www.recash.info/default.asp?lang=en 
Svenska Energiaskor AB - $\underline{\text { http://www.energiaskor.se/ }}$

Etek Etanolteknik AB - http://www.etek.se/main.cfm?sprak=en

BioAlcohol Fuel Foundation - www.baff.info

Svensk Etanol Kemi AB - http://www.sekab.se/eng/

The NILE Project site - http://www.nile-bioethanol.org/

Danish Centre for Biofuels - http://www.biofuels.dk/Forside_UK.htm

European Pellet Centre - http://www.pelletcentre.info/cms/site.asp?p=2554

Cases - bioenergy in Denmark - http://www.opet.dk/biosector/case-bio.htm

Bioenergy and Biofuels Bibliography - http://www.nal.usda.gov/ttic/biofuels/biobib.html

Värmeforsks forskningsprogram miljöriktig användning av askor http://www.askprogrammet.com/

Tidningen Bioenergi - http://www.novator.se/bioenergy/index3.html

Svenska Trädbränsleföreningen - http://www.novator.se/tradbransle/index.html

Pelletsindustins Riksförbund, PiR -

http://www.pelletsbranschen.se/LitiumInformation/site/page.asp?page=1

Svenska Biogasföreningen - http://www.sbgf.org/

Swedish Peat Producers Association - http://www.torvproducenterna.se/index-ENG.shtml

The BASREC web site - http://www.cbss.st/basrec/organisation/

The Organisations for the Promotion of Energy Technologies (OPET) Network http://www.cordis.lu/opet/home.html

Baltic Biomass Network - http://www.balticbiomass.com/content/index.cfm? 


\section{Appendix 2: List of projects on bioenergy issues fully or partly financed by the Nordic Council of Ministers.}

\begin{tabular}{|c|c|c|c|c|}
\hline Project name & Co-ordinator & Financing & Financer & Aim \\
\hline $\begin{array}{l}\text { A simple forest bioenergy decision } \\
\text { support tool for the forest extension in } \\
\text { the Nordic and Baltic countries (BIODST- } \\
\text { BSR). }\end{array}$ & $\begin{array}{l}\text { Inge Stupak Møller } \\
\text { Forest \& Landscape } \\
\text { Denmark } \\
\text { Professor Antti Asikainen, Finnish } \\
\text { Forest Research Institute (METLA) } \\
\text { Finland } \\
\end{array}$ & $\begin{array}{l}\text { 2004: } 696.000 \text { DKK } \\
\text { 2005: } 200.000 \text { DKK }\end{array}$ & Nordic Council of Ministers (NMR) & $\begin{array}{l}\text { - integrate knowledge about economic, socioeconomic, and eco- } \\
\text { logical aspects of forest bioenergy use into a decision support tool } \\
\text { especially for the forest extension. }\end{array}$ \\
\hline $\begin{array}{l}\text { Bioenergy as an environmental factor in } \\
\text { the Nordic-Baltic-North-West-Russian } \\
\text { Region }\end{array}$ & $\begin{array}{l}\text { Dr. Karin Hansen } \\
\text { Forest \& Landscape } \\
\text { Denmark }\end{array}$ & $\begin{array}{l}\text { 2004: } 90.000 \text { DKK } \\
\text { 2005: } 300.000 \text { DKK } \\
\text { 2006: } 60.000 \text { DKK }\end{array}$ & Nordic Council of Ministers (MJS) & $\begin{array}{l}\text { - } \text { provide a broad overview of the current and potential use of bio- } \\
\text { energy in the participating countries } \\
\text { - present and discuss state-of-the-art and needs for future research } \\
\text { - identify key barriers for the sustainable use of bio-energy, } \\
\text { provide policy makers, administrators and scientists with the basis } \\
\text { for debate and future strategies, } \\
\text { - establish Nordic-Baltic-Russian network groups for bridging of gaps } \\
\text { between countries and disciplines, between research and policy } \\
\text { makers, encouraging closer co-operation and sharing of knowledge } \\
\text { - examine possibilities for extending the co-operation to a broader } \\
\text { European level. }\end{array}$ \\
\hline $\begin{array}{l}\text { Nordic Graduate School of Biofuel } \\
\text { Science and Technology }\end{array}$ & $\begin{array}{l}\text { Professor Mikko Hupa } \\
\text { Åbo Akademi } \\
\text { Finland }\end{array}$ & 2003-2006: 17 mill. NOK & $\begin{array}{l}\text { Nordic Energy (Nordisk Energiforsk- } \\
\text { ning) }\end{array}$ & $\begin{array}{l}\text { - Raise the esteem and quality of doctoral training within the Nordic } \\
\text { and Baltic Universities in the area of biofuel and waste conversion to } \\
\text { energy } \\
\text { - Collaboration in post-graduate course arrangements, shared student } \\
\text { supervision by student and supervisor visits between the base uni- } \\
\text { versities, and intensive industry-academia networking. }\end{array}$ \\
\hline BioHydrogen & $\begin{array}{l}\text { Professor Peter Lindblad } \\
\text { Uppsala University } \\
\text { Sweden }\end{array}$ & 2003-2006: 7 mill. NOK & $\begin{array}{l}\text { Nordic Energy (Nordisk Energiforsk- } \\
\text { ning) }\end{array}$ & $\begin{array}{l}\text { - Develop a strong Nordic (including Baltic) research network with } \\
\text { significant graduate student training } \\
\text { - Encourage and support mobility and interactions between Nordic } \\
\text { and Baltic scientists } \\
\text { - Demonstrate, and further improve, significant production of renew- } \\
\text { able bio hydrogen using both photobiological and fermentative path- } \\
\text { ways } \\
\text { - Initiate system analyses on biological systems producing H2 } \\
\text { - Offer shorter, focussed workshops etc to students and younger } \\
\text { researchers in the Nordic/Baltic region } \\
\text { - Position Nordic bio hydrogen research on both the European and the } \\
\text { international arenas }\end{array}$ \\
\hline
\end{tabular}




\begin{tabular}{|c|c|c|c|c|}
\hline Project name & Co-ordinator & Financing & Financer & Aim \\
\hline $\begin{array}{l}\text { Estimation of carbon storage in forest } \\
\text { biomass in the Nordic and Baltic coun- } \\
\text { tries - common methods, protocol and } \\
\text { tools for obtaining comparable biomass } \\
\text { expansion functions (BEF) }\end{array}$ & $\begin{array}{l}\text { Dr. Karin Hansen } \\
\text { Forest \& Landscape } \\
\text { Denmark }\end{array}$ & $\begin{array}{l}\text { 2004: } 450.000 \text { NOK } \\
\text { 2005: } 450.000 \text { NOK } \\
\text { 2006: } 450.000 \text { NOK } \\
70 \% \text { is national finances }\end{array}$ & Nordic Forest Reseach (SNS) & $\begin{array}{l}\text { - Synthesise available knowledge on biomass expansion functions } \\
\text { - Establish common and comparable methods for estimation of carbon } \\
\text { stocks and sequestration in forest stand biomass in the Nordic and } \\
\text { Baltic countries } \\
\text { - Analysis of available data within the group, and exploration of the } \\
\text { uncertainty of the estimated forest carbon stores originating from the } \\
\text { uncertainties of the biomass expansion functions }\end{array}$ \\
\hline $\begin{array}{l}\text { Value chains in forestry } \\
\text { (Verdikjeder i skogsektoren) }\end{array}$ & $\begin{array}{l}\text { Sjur Baardsen } \\
\text { UMB } \\
\text { Norway }\end{array}$ & $\begin{array}{l}\text { 2005: } 300.000 \text { NOK } \\
30 \% \text { is national finances }\end{array}$ & Nordic Forest Reseach (SNS) & $\begin{array}{l}\text { A report which outlines the value chains in forestry. The report evaluates } \\
\text { - the use of private goods - firewood - in the Nordic countries } \\
\text { - the possibilites for further use of wood and wood products } \\
\text { and show how the use of bioenergy play a part in climate change }\end{array}$ \\
\hline $\begin{array}{l}\text { Harvesting of bioenergy in young forest } \\
\text { stands }\end{array}$ & Docent Tomas Nordfjell & $\begin{array}{l}\text { 2005: } 400.000 \text { NOK } \\
\text { 2006: } 400.000 \text { NOK } \\
\text { 2007: } 400.000 \text { NOK } \\
70 \% \text { is national finances }\end{array}$ & Nordic Forest Reseach (SNS) & $\begin{array}{l}\text { - Starting and evaluating technical systems and logistic solutions } \\
\text { which will make the handling of biomass from young forests both } \\
\text { economically and environmentally sound. }\end{array}$ \\
\hline Bio2003-2005Energy & $\begin{array}{l}\text { Gudrun Knutsson } \\
\text { Swedish Energy Agency } \\
\text { Sweden } \\
\text { Ando Leppiman } \\
\text { Ministry of Economic Affairs and } \\
\text { Communications } \\
\text { Estonia }\end{array}$ & ?? & Nordic Council of Ministers & $\begin{array}{l}\text { The overall objective of the project is to support an increased use of } \\
\text { renewable energy in a sustainable way in the Nordic and Baltic region } \\
\text { and thereby enhancing especially the use of bioenergy. The work will } \\
\text { comprise: } \\
\text { - co-ordination and intensified support of the work within the field of } \\
\text { bioenergy } \\
\text { - implementation of an open "Regional Forum for Bioenergy" in order } \\
\text { to exchange and disseminate information and knowledge about local } \\
\text { fuels, methods, actors, techniques and organisations } \\
\text { - to facilitate discussions and co-ordinate co-operation between all } \\
\text { relevant public and private sectors, bodies and organisations repre- } \\
\text { senting, besides the energy sector, for example agriculture and for- } \\
\text { estry, environment, transportation, financing, industry and trade } \\
\text { - surveying of obstacles for an increased use of bioenergy and looking } \\
\text { for relevant solutions } \\
\text { - reporting to the ministerial conference in } 2005 \text { and other relevant } \\
\text { meetings during the mandate period }\end{array}$ \\
\hline $\begin{array}{l}\text { CoReWOOD - Co-operation between } \\
\text { RecAsh, WOOD-EN-MAN and Bio2003- } \\
\text { 2005energy }\end{array}$ & $\begin{array}{l}\text { Dr. Morten Ingerslev } \\
\text { Forest \& Landscape } \\
\text { Denmark }\end{array}$ & $\begin{array}{l}\text { 2004: } 50.000 \text { DKK } \\
\text { 2005: } 150.000 \text { DKK }\end{array}$ & $\begin{array}{l}\text { Nordic Council of Ministers, the } \\
\text { Bio2003-2005Energy project, the } \\
\text { WOOD-EN-MAN project and the } \\
\text { RecAsh project }\end{array}$ & $\begin{array}{l}\text { The objective of the project is to: } \\
\text { enable and promote synergetic co-operation, co-ordination of activities } \\
\text { and knowledge sharing between three main bioenergy projects; RecAsh } \\
\text { (EU) (www.recash.info), WOOD-EN-MAN (EU) (www.flec.kvl.dk/wood- } \\
\text { en-man) and Bio2003-2005energy (Basrec) } \\
\text { (http://www.cbss.st/basrec/). }\end{array}$ \\
\hline
\end{tabular}

